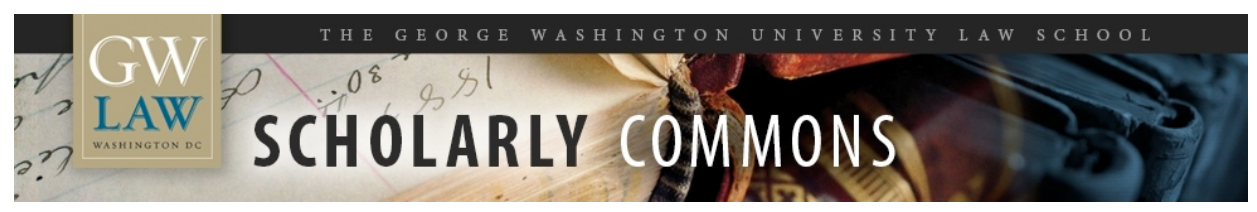

\title{
From Expert Administration to Accountability Network: A New Paradigm for Comparative Administrative Law
}

\author{
Francesca Bignami \\ George Washington University Law School, fbignami@law.gwu.edu
}

Follow this and additional works at: https://scholarship.law.gwu.edu/faculty_publications

Part of the Law Commons

\section{Recommended Citation}

Francesca Bignami, From Expert Administration to Accountability Network: A New Paradigm for Comparative Administrative Law, 59 Am. J. Comp. L. 859 (2011)

This Article is brought to you for free and open access by the Faculty Scholarship at Scholarly Commons. It has been accepted for inclusion in GW Law Faculty Publications \& Other Works by an authorized administrator of Scholarly Commons. For more information, please contact spagel@law.gwu.edu. 


\title{
From Expert Administration to Accountability Network:
}

\author{
A New Paradigm for Comparative Administrative Law
}

\author{
Francesca Bignami*
}

Notwithstanding the radically changed landscape of contemporary administrative governance, the categories that guide comparative administrative law and that determine what will be compared remain similar to those used at the founding of the discipline in the late 1800s. These categories are rooted in confidence in an expert bureaucracy to accomplish public purposes and are mainly twofold - administrative organization and judicial review. This outdated model has limited the ability of comparative law to engage with contemporary debates on the administrative state, which instead display considerable skepticism of public administration and are premised on achieving the public good through a plural accountability network of public and private actors. This Article seeks to correct the anachronism by reframing comparative administrative law as an accountability network of rules and procedures designed to embed public administration and civil servants in their liberal democratic societies: accountability to elected officials, organized interests, the courts, and the general public. Based on this paradigm, the Article compares American and European administrative law in a global context. Among the many differences explored are parliamentary versus presidential political control, pluralist versus neo-corporatist forms of self-regulation and public-private collaboration, judicial review focused on fundamental rights versus policy rationality, and reliance on ombudsmen in lieu of courts. The Article concludes with a number of suggestions for how comparative law can speak to current debates on reforming administrative governance.

\footnotetext{
* Professor of Law, George Washington University Law School. Email: fbignami@law.gwu.edu. I would like to thank Jürgen Bast, Jacco Bomhoff, Sabino Cassese, Carol Harlow, Herwig Hofmann, Peter Lindseth, Ralf Michaels, Mathias Reimann, Giorgio Resta, Susan Rose-Ackerman, and the participants in the Royal Netherlands Academy Colloquium on Comparative Methodology for their suggestions and comments.
} 


\section{TABle OF CONTENTS}

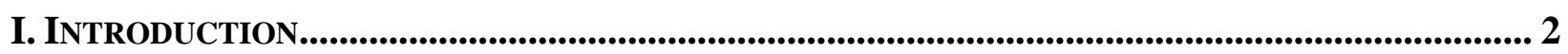

II. The Traditional Canon OF Comparative Administrative LaW....................................... 5

III. Towards a New Paradigm: Administrative LaW as ACCOUnTability Network .. 15

IV. The Four ACCOUNTABILITY Relationships of Public AdMinistration....................... 20

A. Administration and Elected Officials.................................................................................... 23

B. Administration and Organized Interests ............................................................................. 28

C. Administration and the Courts..................................................................................... 35

D. Administration and the Public...................................................................................................... 46

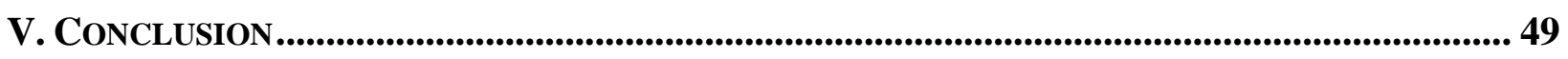

\section{INTRODUCTION}

Theories of administration and administrative law have changed dramatically in recent times. The traditional hierarchical image of state bureaucracy has been confronted by an increasingly disaggregated reality of autonomous service-delivery bodies, independent regulatory agencies, newly powerful local governments, and a plethora of transnational and international regulatory bodies. Private actors, ranging from industry self-regulatory bodies, to individual firms, to public interest groups, are now recognized as vital participants in the administrative process, sometimes as substitutes for public administration, sometimes as critical collaborators. A number of procedural innovations have rendered the administrative process more transparent, participatory, and flexible than before, thereby empowering the expanded constellation of public and private actors to actively shape and check administrative action. Fittingly, in the work of legal and public policy scholars focused on domestic and, increasingly, transnational administrative systems, the old notion of an expert bureaucracy swiftly carrying out the democratic will has 
been replaced by a networked understanding of how public and private actors combine to accomplish administrative purposes. ${ }^{1}$

Comparative administrative law, which seeks to uncover the similarities and differences that mark multiple legal systems, has failed to keep abreast of this transformation of the administrative landscape. The categories and concepts that determine what will be compared have not changed much since the beginning of the field, back in the late 1800s. These categories and concepts are mainly twofold: the organization of public administration and the judicial review of administrative action. This intellectual framework is rooted in the historical origins of the field, which was characterized by a spectacular confidence in the ability of a professional bureaucracy to fulfill the purposes of society. Administrative law was cast as a set of rules and procedures designed to promote effective administrative action and a series of remedies, afforded by the courts, should public administration exceed the limits of these rules and procedures. Although it is certainly true that, over the past decade, a number of high-quality comparative studies have shed light on important innovations in administrative law that were never imagined by the founders of the discipline, these studies are limited to a single institution, procedure, or standard without the ambition of mapping entire systems of administrative law. ${ }^{2}$ Broad-gauged comparisons, in contrast with the issue-specific literature, continue to be marked by the old paradigm of a hierarchical public administration accomplishing public purposes under the supervision of courts checking for fidelity to enabling legislation.

For comparative research that wishes to engage with contemporary debates on the desirability and future possibilities of administrative law, it is essential that the concepts that guide comparison reflect current understandings of legitimate administrative governance. Without categories that are informed by contemporary theories of the administrative state, the legal data that fill the categories-variations and commonalities in rules, procedures, and institutions - will speak past the many questions that arise in current good governance debates. In this Article, I seek to develop such a comparative framework by recasting administrative law

\footnotetext{
${ }^{1}$ See, e.g., Jody Freeman, Collaborative Governance in the Administrative State, 45 UCLA L. REV. 1 (1997); Adrienne Héritier \& Martin Rhodes, New Modes of Governance, in NEW MODES OF GOVERNANCE IN EUROPE 163 (Adrienne Héritier \& Martin Rhodes eds., 2011); Orly Lobel, The Renew Deal: The Fall of Regulation and the Rise of Governance in Contemporary Legal Thought, 89 MINN. L. REV. 342 (2004).

2 See, e.g., Agencies in Comparative And European Perspective (Luc Verhey \& Tom Zwart eds., 2003); Comparative Administrative Law (Susan Rose-Ackerman \& Peter L. Lindseth eds., 2010); THE PubliCPRIVATE LAW Divide: Potential FOR TRANSFORMATION? (Matthias Ruffert ed., 2009).
} 
as an accountability network of rules and procedures through which civil servants are embedded in their liberal democratic societies. The concept of an accountability network is broken down into four major sets of relations: between civil servants, on the one hand, and elected officials, organized interests, the courts, and the general public on the other hand. This scheme shifts attention away from administrative action by state bureaucracies and towards the multiple public and private actors that participate in administrative governance and that shape and check the exercise of administrative power.

The accountability-network paradigm advances the literature in a number of ways. It focuses attention on two sets of actors-organized social and economic groups and members of the general public - that have traditionally been inconsequential in comparative analysis. While industry self-regulation, public-private administration, and participation rights, discussed in the section on organized interests, and transparency norms and ombudsmen, part of the section on diffuse accountability, are routinely put forward as indispensable to administrative governance, standard overviews of comparative administrative law either omit these topics altogether or mention them but briefly in their discussions of administrative procedure and judicial review. By expressly recognizing these two forms of accountability, the proposed framework brings attention to national practices that should be considered in contemporary discussions on the merits of different forms of public-private collaboration and oversight by the general public. The proposed framework also contributes to the literature by shedding light on old forms of accountability that are staples of the field—oversight by elected officials and judicial review. The prevalence of the conventional model of an expert administration acting within the confines of the law has obscured the wide range of priorities and legal standards at play in the two types of accountability relations. Executive-branch officials act not only to promote efficient and coherent administration, as was explained in early comparative scholarship, but also to infuse the administrative process with their own political objectives. Judicial review for fidelity to legislative commands - the classic understanding of the rule of law — is today complemented by scrutiny for policy rationality, adherence to fundamental rights, and compliance with procedural guarantees. In sum, a conceptual framework based on a multi-faceted accountability network, rather than an antiquated, hierarchical public administration, is better equipped to capture the complex empirical realities and normative self-understandings of contemporary administrative governance. 
The first section of this Article presents the blueprint of administrative organization and courts that inspired early administrative law scholarship, going as far back as 1893 with the monumental comparative study authored by the American legal scholar Frank Goodnow, and reflected in the work of other pioneers of the field in the United States, France, and Germany. It also explores the transformations in state capacity and public attitudes that necessitate a shift away from the old focus. In section two, I explain my alternative theoretical framework. Section three, the heart of the Article, discusses the legal similarities and differences that fill the conceptual containers, with a primary geographic focus on the United States and Western Europe. Among the many differences reviewed are professionalized versus politicized civilservice recruitment, parliamentary versus presidential political control, pluralist versus neocorporatist forms of self-regulation and public-private collaboration, judicial review focused on fundamental rights versus policy rationality, and reliance on ombudsmen in lieu of courts. The conclusion raises additional research questions and discusses how some of the comparative law revealed by the accountability-network paradigm can inform contemporary policy debates on reforming administrative governance.

\section{The Traditional Canon of Comparative Administrative LaW}

The birth of administrative law as an academic discipline is inextricably tied to the rise of large state bureaucracies in the late nineteenth century. This was a period of great optimism in the ability of public servants and the bureaucratic form of organization to pursue the common good and advance the interests of society as a whole. The era is nicely captured by the intellectual historian Pierre Rosanvallon in his analysis of changing understandings of democratic legitimacy from the French Revolution to the present day. ${ }^{3}$ As he explains, for most of the nineteenth century, the ideal of government by the people was largely conceived as the political practice of universal suffrage, elections, and majority rule. Yet in both France and the United States, the pathologies of party politics — government instability and the corruption of elected officials_led many thinkers to sour on the idea of majoritarian politics and to seek complementary forms of government that would guarantee sound public ordering. Public administration emerged as that

\footnotetext{
${ }^{3}$ Pierre RosanVAllon, LA LÉGITIMITÉ dÉMOCRATIQUE: IMPARTIALITÉ, RÉFleXIVITÉ, PROXIMITÉ 59-99 (2008).
} 
complementary form of organization in both France and the United States and, one might add, most of the Western world.

The many ways in which government by bureaucrats was conceptualized as government for the people are critical to appreciating how thoroughly entrenched public administration was in the democratic theory of the time. In France, the pioneering work of the first generation of social scientists portrayed society as composed of multiple groups, organized by economic function, territorial allegiance, religious affiliation, and other attributes, and organically interwoven to constitute a single social whole. This vision of society prompted the great legal thinkers Léon Duguit and Maurice Hauriou to develop a theory of administration in which government officials would direct state resources to integrating the different parts into a coherent whole and to nurturing the many forms of solidarity through which individuals became members of society. ${ }^{4}$ This theory of administration as provider of the "public services" objectively needed by society called for an enlightened cadre of public officials, capable of discerning what these public services might be and adept at putting them into action. Indeed, according to this theory, civil servants themselves formed a distinct social group, essential to the constitution of society.

In the United States, democratic faith in public administration took on a somewhat different shape. Progressives like Woodrow Wilson and Frank Goodnow, and later on, New Dealers like James Landis, campaigned for an independent, career civil service based on the values of the scientific managerialism of the age: administration, like many other spheres of human activity, was a science and only a cadre of devoted public servants could master its theories and techniques. As Goodnow put it in justifying the separation of administration from party politics:

[T] here is a large part of administration which is unconnected with politics, which should therefore be relieved very largely, if not altogether, from the control of political bodies. It is unconnected with politics because it embraces fields of semiscientific, quasi-judicial, and quasi- business or commercial activity . . . For the most advantageous discharge of this branch of the function of administration there should be organized a force of governmental agents absolutely free from the influence of politics. Such a force should be free from the influence of politics because of the fact that their mission is the exercise of foresight and discretion, the pursuit of truth, the gathering of information, the maintenance of a strictly

\footnotetext{
${ }^{4}$ Hugh Stuart Jones, The French State in Question: Public Law and Political Argument in the ThiRd REPUBLIC 60-195 (1993).
} 
impartial attitude towards the individuals with whom they have dealings, and the provision of the most efficient possible administrative organization. ${ }^{5}$

These ideas took a long time to percolate into political reality and mainstream policy thinking, as the drawn-out battle over civil service reform demonstrates, but by the 1920s, the bulk of the federal civil service had been professionalized. ${ }^{6}$

The situation in Germany was different still. In the view of legal scholars, public administration was coterminous with the state and national sovereignty. ${ }^{7}$ It was the essential tool for accomplishing the purposes and the interests of the state. As Otto Mayer, the giant of the field through the end of World War I, wrote:

The State is a people organized for the pursuit of its interests, under a sovereign power. The administration is the activity of the State for the accomplishment of its ends. ... . [T] he administration signifies the formation of the sovereign power by which the State becomes capable of acting. ${ }^{8}$

This state, on the behalf of which the administration acted, was conceived in highly abstract and formal terms, largely as the power of command and domination, and was severed from a substantive vision of the right political process or the real social order that was to be expressed by the state. ${ }^{9}$ Likewise, the essence of administration was command: administrative acts addressed to individuals and immediately binding and enforceable, which determined what was lawful in the particular circumstances. ${ }^{10}$

The legal historian Michael Stolleis ascribes the partiality of German scholars to the authority dimension of administration to both the conservative intellectual milieu of the time and the Pandectist method embraced by the mainstream legal academy. ${ }^{11}$ Most law professors were middle class and monarchist and therefore not inclined to expose the many democratic

\footnotetext{
${ }^{5}$ FRANK J. GOODNOW, POLITICS AND ADMINISTRATION 85 (1914).

${ }^{6}$ See StePHEN SKOWRONEK, BUILDING a NeW AMERICAN STATE 48-209 (1982).

${ }^{7}$ See LuCA MANNORI \& BERNARdo Sordi, StORIA DEL DiRITTO AMMinistrativo 376 (2001); Michael StOlleis, Public LaW IN GERmanY, 1800-1914, 402 (2001). Although this section is limited to the United States, Germany, and France, it should be noted that Italian administrative law was heavily influenced by German doctrinal writing; the Pandectist method, with its focus on administrative acts, was also emblematic of Italian scholarship. See Bernardo Giorgio Mattarella, Administrative Law in Italy: An Historical Sketch, RIVISTA TRIMESTRALE DI DIRITTO PUBBLICO 1009 (2010).

${ }^{8}$ OtTO MAYer, 1 Le Droit ADMinistratif ALlEMAND: PARTIE GÉNÉRALE 1(Paris, V. Giard \& E. Brière 1903).

${ }^{9}$ See STOLLEIS, supra note 7, at 318.

${ }^{10}$ See MANNORI \& SORDI, supra note 7, at 376; id. at 395.

${ }^{11}$ STOLLEIS, supra note 7 , at 329.
} 
shortcomings of the Prussian state and the German Empire. The methodological component of Stolleis's explanation is more complex. Pandectist scholars sought to distance public law from philosophy and history and to render it scientific and free from value judgments. The ambition was to use logic and analogy to construct higher-level, abstract concepts that could order the entire legal universe and thus serve as the basis for resolving the myriad concrete legal disputes arising in the day-to-day administration of the system. The formalism of the Pandectists was manifestly different from contemporary legal positivism: the latter is generally (and unfairly) characterized as the mechanical application of legal rules to facts and the deduction of outcomes from legal sources whereas the former first constructs higher-level concepts from the rules and then uses these concepts to resolved concrete legal issues. Thus Stolleis describes the work of Paul Laband, the preeminent constitutional law scholar and Pandectist par excellence, as follows:

His material is ... directed at the general fundamental concepts of constitutional law ... extracted by "pure logical ratiocination" [from the positive constitutional laws of the Empire] to achieve the "unified fundamental and leading principles," to a certain extent the intellectual essence of the changeable decisions of positive law. . . . These rules - created by the construction of analogies and by the exclusion of contradictions by means of contextualization with the variously disposed materials - are made into "concepts" and "legal institutions," that is, intellectual, artificial products completely receptive to hidden prejudices. ${ }^{12}$

In the Pandectist method, the positive enactments of state actors-constitution-makers and legislators - served as the neutral and authoritative bedrock upon which the scientific edifice of law was built. The mission of the academy was not to assess critically laws and implementing acts, based on natural law or a normative theory of good government, but rather to systematize and rationalize the sources, which derived their foundational status from their quality as commands of the state.

Notwithstanding these national permutations, faith in public administration was broadly shared and was reflected in the study of administrative law. The treatises of early administrative law scholars all placed the efficient action of administrative officials at the center of their analysis. Frank Goodnow was one of the pioneers of the field in the United States and he also authored one of the first comprehensive English-language studies on comparative administrative

\footnotetext{
${ }^{12} I d$. at 325 .
} 
law. ${ }^{13}$ His exposition of the administrative law of the United States, France, England, and Germany revolved around the organization, powers, and procedures of public administration: the hierarchical lines of control extending from central to local government offices, the relationship between elected and career officials, the different types of acts promulgated by administration, and the various ways of giving effect to administrative orders. To ensure that these powers would be used for their intended purpose, administrative officials were placed under the watchful eye of executive-branch superiors, the courts of law, and the legislature. In his account, each body was charged with a different form of oversight: executive-branch superiors with efficiency, courts with rights, and the legislature with societal welfare. ${ }^{14}$ And even though it is evident from this tri-partite scheme that Goodnow had a broad understanding of oversight, his analysis was mainly devoted to the courts: tort suits against government officials, criminal prosecutions of renegade public officers, and lawsuits against administrative acts in those instances where a tort or criminal action would be inadequate. In sum, administrative law was cast as the set of rules that served as the backbone of state bureaucracy, designed to allow public administration to pursue vigorously the common good without trampling on rights. When all was said and done, administrative law boiled down to two components: administrative organization and judicial review.

Ernst Freund, another early scholar of American administrative law whose writings also included a comparative dimension, focused even more squarely on the twin categories of administrative action and judicial review. His comparative study of the United States, New York, England, and Germany was organized by the types of powers exercised by administrative bodies and the judicial remedies available to individuals harmed by public administration. ${ }^{15}$ Based on an extensive analysis of primary sources in the areas of public utilities, merchant shipping, insurance, trade, labor, health and safety, and regulation of the professions, he identified four types of administrative power-enabling, determinative, examining, and summary. The second part of his study consisted of a description of the different court systems in existence in Germany

\footnotetext{
${ }^{13}$ Frank J. GoOdnow, Comparative Administrative LAW: An ANAlysis of the Administrative Systems, NATIONAL AND LOCAL, OF THE UNITED STATES, ENGLAND, FrANCE AND GERMANY (1893).

${ }^{14} I d$. at $135-37$.

15 ERnst Freund, Administrative Powers over PERSONS AND Property (1928). For a discussion of Freund's scholarship, see John Reitz, The Influence of Ernst Freund on American Law, in DER EINFLUSS DEUTSCHER EMIGRANTEN AUF DIE RECHTSENTWICKLUNG IN DEN USA UND IN DEUTSCHLAND 423 (Marcus Lutte et al. eds., 1993).
} 
and the common law world, the various theories of government liability and administrative illegality in operation in administrative litigation, and the remedial powers of courts. His treatment of the subject was more parsimonious than Goodnow's-omitting topics such as executive and legislative oversight — but like Goodnow, Freund compared by first charting administrative authority and then describing the countervailing power of courts to curb administrative discretion and guarantee government in accordance with law.

In continental European scholarship, administrative action and judicial redress were also critical themes. In his foundational treatise on German administrative law, Otto Mayer stressed that one of the most important characteristics of the contemporary state was the rule of law: whereas before, in the "police regime" of absolute monarchy, there was no public law to bind the administration, in the contemporary state, with the separation of legislative and executive power, the law had to authorize administrative action and such action had to conform to the rules set down in law. ${ }^{16}$ Equally essential to his account of the rule of law was the administrative act. The administrative act was theoretically important because it represented the moment at which the law took effect in the individual case and the work of civil servants acquired significance for the legal system. Something considered an administrative act had immediate, binding force, demanded compliance from individuals, conferred rights and powers, and deserved recognition from the rest of the legal system, in particular the courts. Vice versa, only administrative acts could be challenged before independent tribunals. Mayer expended considerable energy on unpacking the types of administrative acts that could be issued by state officials - for instance, the distinction between acts that created new duties and those that gave effect to duties previously set down by legislation - and exploring the various rights and duties that attached to these different administrative acts. The last part of his treatise was devoted to forms of redress against the administration, both internally through hierarchical appeals and externally through challenges before administrative tribunals in the event of illegal administrative acts and before civil tribunals in government liability cases. The rule-of-law ideal underpinned both the authority of public administration and the availability of legal redress: the legislative rules from which administrative acts derived their authority were the very same rules upon which individual could rely in seeking to invalidate administrative determinations. Individual rights were conceived not

\footnotetext{
${ }^{16}$ MAYER, supra note 8.
} 
as free-standing entitlements but rather as the creature of the positive enactments of state legislators - not "rights" but "interests" in Mayer's terminology.

Maurice Hauriou's treatise on administrative law affords an insight into French scholarship at the turn-of-the-century. ${ }^{17}$ The theory of public services, described above, infused his entire discussion: the task of administration was to provide public services and execute parliamentary enactments and the object of legal scholarship was the powers and procedures used by administrative persons, i.e., administrative bodies and quasi-public entities, to ensure the operation of public services. Through public services, the many threads of the social fabricfamily, market, and church —were rationally ordered and political unity was achieved. Having established this basic mission of administration and administrative law, Hauriou proceeded in a fashion similar to Goodnow. He first described the organization of public administration, including the executive and legislative organs of the central state, regional administration, local government, the colonies, and specialized public agencies. Hauriou then provided an elaborate analysis of the different types of administrative acts promulgated by administration and gave a long and detailed list of the different powers and procedures used by the various administrative bodies covered in the previous section. He concluded with individual challenges to administrative acts and administrative litigation in the Council of State. To be sure, significant differences separated the French and Germans from the Americans: while both Goodnow and Freund divided their works roughly equally between administration and administrative powers on the one hand and courts on the other hand, the treatises of Hauriou and Mayer were weighted more heavily towards the organization, acts, and powers of administration, with relatively little space dedicated to administrative litigation. Nonetheless, the same two themes guided all of these giants of the first generation of administrative law scholarship - the powers and procedures that enabled administrative action and the judicial safeguards against abuse of these powers and procedures.

Since these pioneers of the field first wrote, the model of public well-being achieved through the efforts of enlightened government bureaucrats under the occasional supervision of courts has come under extensive pressure. The challenge to administrative legitimacy has been a

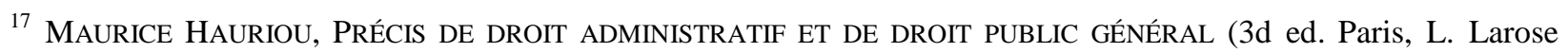
1897).
} 
long time in the making and has come from both the public and the market, the left and the right. ${ }^{18}$ Citizens concerned with environmental safety, consumer protection, and other matters of public welfare have come to distrust technocratic expertise and the close ties between government administration and the business community, and they have sought, and obtained, various forms of transparency, direct participation, and openness in public decision making. Champions of deregulation have forced public administration to withdraw from many areas of goods and services provision and have introduced a series of market-based reforms of the public sector. Beginning in the 1990s, reformers on both sides of the political spectrum have advocated more collaborative relations between government regulators, industry actors, and the public-atlarge-through public consultations, soft law, open-ended norms, and self-regulation. ${ }^{19}$ Fundamental rights, in particular in Europe, have come to permeate the work of government administration, with the expanding powers of constitutional courts and the development of a thick human rights discourse across multiple levels of government. ${ }^{20}$ Last, but not least, globalization and the rise of transnational governance have also taken their toll: the status of state administration as the central pillar of good government has inevitably suffered with the growing necessity of multilateral cooperation among a variety of state and non-state actors to handle the innumerable problems that spill across national borders in a globalized world. ${ }^{21}$

In keeping with these developments, the depiction of public administration and administrative law to be found in contemporary legal and public policy scholarship is markedly different from what was on display in the work of the first generation of scholars. ${ }^{22}$ The old image of a hierarchical public administration single-handedly implementing well-defined policy goals set down in legislation must today compete with a vision of the administrative process as open-ended, collaborative, and networked. In this alternative understanding, the key to success is to enlist stakeholders - private firms, workers, consumers, and all those affected by regulation-

\footnotetext{
${ }^{18}$ See RosanVallon, supra note 3, at 14-15; Richard B. Stewart, Administrative Law in the Twenty-First Century, 78 N.Y.U. L. REV. 437, 440-44 (2003); EZRA SulEiman, DisMantling DEMOCRATIC STATES (2003).

${ }^{19}$ See, e.g., Marc Allen Eisner, Corporate Environmentalism, Regulatory Reform, and Industry Self-Regulation, 17 GOVERNANCE 145 (2004).

${ }^{20}$ See, e.g., ALEC STONE SWEET, GOVERNING WITH JUDGES (2004).

${ }^{21}$ See, e.g., SABINO CASSESE, IL DIRITTO GLOBALE (2009).

${ }^{22}$ See, e.g., Freeman, supra note 1; Robert E. Goodin et al., The Public and Its Policies, in The OXford HandBook OF PUBlic POLICY 3 (Michael Moran et al. eds., 2006); Héritier \& Rhodes, supra note 1; Lobel, supra note 1; R.A.W. Rhodes, Policy Network Analysis, in THE OXFord HANDBOOK OF PUblic Policy 425, supra; Charles F. Sabel \& Jonathan Zeitlin, Learning From Difference, in EXPERIMENTALIST GOVERNANCE IN THE EUROPEAN UNION 1 (Charles F. Sabel \& Jonathan Zeitlin eds., 2010).
} 
in devising, implementing, and enforcing regulatory norms in the many arenas in which the government is called upon to act. In these accounts, the task of public administration has been scaled back considerably — from commanding, to persuading and steering. Private actors, by contrast, have come to assume an enormously important role, not only at the domestic level, but in global regulation, as has been highlighted by scholars of the many self-regulatory and publicprivate schemes that have blossomed at the international level. ${ }^{23}$ Likewise, in contemporary teaching and scholarship, judicial review for fidelity to enabling laws has been supplemented by a host of additional control mechanisms and substantive considerations. ${ }^{24}$ Public officials must beware not only of courts policing for the rule of law but also ombudsmen, parliamentary oversight committees, constitutional rights, transparency guarantees, and supranational regulatory committees.

In some respects, research on comparative administrative law has paralleled the shift in contemporary legal and public policy scholarship. Over the past decade, a number of highquality studies have sought to incorporate the new understandings of administrative governance into comparative law by focusing on important developments such as the privatization of public services, the proliferation of independent regulatory agencies, and cost-benefit analysis. ${ }^{25}$ This scholarship, however, in contrast with the sweeping treatises of Goodnow and Freund, focuses on a particular type of institution, procedure, or standard in isolation, without the ambition of comparing entire systems of administrative law and examining the wide range of dimensions on which the world's systems converge and diverge. It also tends to be concentrated in edited volumes, which offer the advantage of broad coverage in geographic scope and subject matter, but which can make it difficult to draw strong conclusions because of the methodological diversity of the individual contributions.

What, then, of scholarship that attempts to map administrative law systems across the world? Does it compare and contrast collaborative governance schemes, public-private partnerships, oversight by ombudsmen and parliamentary committees, and the many other

\footnotetext{
${ }^{23}$ Kenneth W. Abbott \& Duncan Snidal, The Governance Triangle, in The Politics of Global Regulation (Walter Mattli \& Ngaire Woods eds., 2009).

${ }^{24}$ See, e.g., Legal Challenges IN EU Administrative LaW (Herwig C.H. Hofman \& Alexander H. Türk eds., 2009).

25 See, e.g., Agencies in Comparative AND European Perspective, supra note 2; Comparative Administrative LAW, supra note 2; The PUblic-Private LAW Divide: POTENTIAL FOR TRANSFORMATIOn?, supra note 2 .
} 
elements of contemporary administrative law? The answer, on the whole, is "No." To be sure, these new topics are sometimes mentioned, but only briefly, because they are tacked onto a framework that betrays an older conception of expert administration carrying out legislative commands under the watchful eye of courts. The essential themes that indicate what will be compared - the similarity in subject necessary before comparison can begin - remain strikingly similar to those of the first generation of administrative law scholars: ${ }^{26}$ Which organizational structures, policy instruments, and legal procedures are in place to assist government officials in accomplishing public purposes? And what judicial remedies are available to individuals should civil servants fail to abide by their mandate?

There are many examples of the persistence of this two-fold scheme of administrative organization and judicial review. In his overview of the field of comparative administrative law, the prominent English legal scholar, John Bell, writes that:

[A]dministrative law establishes both primary rules governing how the administration is authorized to work (its organization, powers, and procedures), as well as the secondary rules governing the remedies (judicial or other) available in cases of a failure to observe the primary rules. ${ }^{27}$

Jacques Ziller, a leading French scholar, introduces the field and his sweeping overview of European systems in these terms:

Administrative law is therefore the theoretical framework for the action of administrative bodies [appareils administratifs], which conditions not only their action but also their administrative organization strictly speaking . . . Administrative bodies . . . require control . . political, hierarchical, and judicial. $^{28}$

Michel Fromont, in his illuminating and masterful exploration of twelve different European administrative law systems, divides his work into two parts: the fundamentals of administrative law, by which he means primarily the organization of administration and judicial review, and litigation against public administration, divided by type of administrative action. ${ }^{29}$ These various

\footnotetext{
${ }^{26}$ See Gerhard Dannemann, Comparative Law: Study of Similiarties or Differences?, in THE OXFORD HANDBOOK OF COMPARATIVE LAW 383, 407 (Mathias Reimann \& Reinhard Zimmerman eds., 2008).

${ }^{27}$ John S. Bell, Comparative Administrative Law, in THE OXford HANDBOOK OF COMPARATIVE Law, id., 1259, 1261.

${ }^{28}$ JACQUES ZILLER, ADMINISTRATIONS COMPARÉES: LES SYSTEMS POLITICO-ADMINISTRATIFS DE L'EUROPE DES DOUZE 270-71 (1993).

${ }^{29}$ Michel Fromont, Droit ADMinistratif DES ÉtATS EUROPÉENS (2006).
} 
attempts to define the field and set out the categories for comparison all echo the work of the early pioneers of administrative law. To bring home the point, it is worthwhile returning again to Frank Goodnow. In the preface to his treatise on comparative administrative law, he tells us:

[The author's] intention has been . . . to set forth, in the first place, the methods of administrative organization in the four countries whose law is considered, namely the United States, England, France, and Germany, and to state in the second place, somewhat in detail, the means of holding this organization up to its work, and of preventing it from encroaching on those rights which have been guaranteed to the individual by the constitution or laws. ${ }^{30}$

In sum, comparative administrative law writ large still bears the indelible mark of an older vision of the administrative state.

\section{Towards a New Paradigm: Administrative Law as AcCountability Network}

The experience of the world's many administrative law systems can be brought to bear on current debates only if the framework that guides comparison is informed by the categories and concepts of legitimate administrative governance as they are understood today. Without a modernized theoretical scheme, the comparatist risks gathering data on dimensions of administrative law that are now largely perceived as inconsequential while neglecting those dimensions that are believed to be critical to the operation of good government. To capture the new reality, comparative administrative law should be framed no longer as the rules and judicialredress mechanisms that guarantee the effective working of administration but rather as an accountability network through which civil servants are embedded in their liberal-democratic social orders. Such a network concept underscores a number of essential features of the contemporary administrative process. ${ }^{31}$ It highlights the multiplicity of public and private actors involved in administrative decision making as well as the lack of hierarchy among these actors as a device for evaluating their relative weight and resolving disputes among them on a routine basis. The network concept also calls attention to the way in which legal rules and procedures serve to create relations among the different units of the network. It is important to focus on

\footnotetext{
${ }^{30}$ GoODNOW, supra note 13 , at iii.

${ }^{31}$ See generally Michael D. Ward et al., Network Analysis and Political Science, 14 ANN. REV. POL. SCI. 245, 24849 (2011); Emilie Hafner-Burton et al., Network Analysis for International Relations, 63 INTERNATIONAL ORGANIZATION 559 (2009). This Article engages in what Ward et al. calls a "qualitative and analogical analysis of networks" and what Hafner-Burton et al. refer to as the study of the "network form of organization."
} 
these relations, not simply on the characteristics of the individual units and in particular the technocratic expertise of public administration, to understand and explain administrative outcomes.

In my scheme, the accountability network is broken down into several elements to reflect the different types of incentives, actors, and institutional logics that shape administrative outcomes. There are four major accountability relations in administrative governance: relations between public administration, on the one hand, and elected politicians, organized interests, the courts of law, and the general public, on the other hand. ${ }^{32}$ The law to be compared is the law that enables the resulting four types of accountability, thus empowering these four sets of actors and unleashing their distinct motives and logics of action in the administrative process. These are the problems that are common to administrative law in liberal democratic societies and that can properly serve as a springboard for comparing the similarities and differences of administrative law systems worldwide.

The conceptual shift from a vertically organized public administration to a plural accountability network of government bureaucrats and public and private actors broadens the horizons of comparative analysis and enables a more productive exchange with good governance debates in a number of ways. First, the network understanding of administrative action shines light on two major sets of actors, together with their distinct legal rules and procedures, which have traditionally been ignored in comparative analysis: organized social and economic groups, and members of the general public. Self-regulation, advisory committees, joint public-private management, transparency norms, and independent ombudsmen are all elements of administrative law that have either been omitted altogether from comparative studies or that have appeared as brief footnotes to judicial review and administrative procedure. Yet in discussions on the future of administrative governance in both national and international settings, these instruments and procedures all figure prominently as some of the most promising avenues for improving legitimacy and extending regulatory capacity. To understand and evaluate such

\footnotetext{
32 Another important node of administrative networks is the transnational component. National civil servants are in constant interaction with foreign regulators, international bodies, and transnational regulatory committees, which both shape and check their exercise of administrative authority. By definition, however, the transnational dimension of the contemporary administrative process should operate in the same fashion and impose the same legal duties regardless of which national system is caught by the transnational governance web. In other words, transnational accountability does not serve as an intellectual placeholder for examining the differences and similarities that mark multiple legal systems and therefore it is not considered in this analysis.
} 
trends, it is natural to look to the comparative experience of national systems of administrative law but because comparative studies have treated socio-economic participation and diffuse public accountability as unimportant, the debate has been inadequately informed by the current realities of the field. Scholarship on these subjects certainly exists, and I make use of it later in the Article, but it is scattered and generally not comparative. Self-regulation, for example, is typically described in specialty literatures, such as environmental law and the law of the professions, is rarely analyzed as a general administrative law phenomenon, and even more rarely examined in comparative perspective.

The second contribution of the accountability-network paradigm is that it recognizes the expanded role of courts and elected politicians in administrative governance. Although oversight by elected representatives and judicial review are important subjects of virtually all comparative scholarship, the centrality of expert public administration in the collective imagination has given rise to a stunted vision of the incentives and legal considerations that motivate these actors in the administrative process. To demonstrate the limitations of the old mindset for understanding executive-branch oversight, let us return again to Goodnow. He lauded the American system of presidential power over heads of department not because the President was directly elected and therefore could inject various political priorities into the administrative process, but because of the vigorous administrative action that would be promoted by such a clear chain-of-command:

[I]n the national administration the heads of the departments are completely subordinate to and dependent upon the chief executive authority as a result of the precariousness of their tenure and will be in harmony one with the other and with the President .... We find therefore in the national administration complete guaranties for an efficient and harmonious administration under the direction of the President. ${ }^{33}$

Likewise, judicial review was largely conceptualized as checking for violations of enabling statutes. Thus, for instance, Otto Mayer identified two main forms of legal challenges that could be brought in the German system: the claim of a violation of parliamentary law and the contention that the facts necessary for establishing the statutory basis for administrative action were absent. ${ }^{34}$ If, instead, elected officials and courts are treated as independent sites of political and social contention, with their distinct logics of action and incentive structures, then it is

\footnotetext{
${ }^{33}$ GoODNOW, supra note 13 , at 136.

${ }^{34}$ MAYER, supra note 8, at 247-50.
} 
possible to admit a more complex set of priorities and legal standards that shape and constrain the work of government bureaucrats. Thus, as will be explained below, the competing political agendas of elected officials can affect public administration in unexpected ways and the judicial branch, in reviewing administrative action, can impose standards of procedure, rationality, and fundamental rights that go well beyond mechanical policing for fidelity to authorizing legislation.

The third innovation of the framework proposed here is related to the first two: the ambition of modernizing comparative administrative law is accomplished partly by drawing on the extensive research in the social sciences on the administrative state, both to construct the four categories for comparison mentioned before and to understand, within each of them, which legal similarities and differences merit discussion. In contrast with other areas of comparative law like contracts and torts, which are typically perceived as highly technical and therefore of little interest outside the law, the legal regulation of administration has attracted considerable attention from scholars interested in the history of the state and comparative politics. For the most part, however, comparative administrative law scholarship has failed to look to this wealth of empirical material. Rather, it has adopted what H.L.A. Hart would call an "internal point of view": it has used the status of a rule in the national hierarchy of norms as a signal of what is truly important and therefore deserves to be included in a comparative overview. Whether a legal rule is written in a constitution, is set down in a foundational law like an administrative procedure act, or is pronounced by a high court is certainly an indicator of how powerful that rule is in setting the legal parameters of administrative governance. In the substantive discussion which follows, I too consider many of these high-level limitations on administrative action. Yet, as a criterion for deciding what to compare, pedigree has a significant shortcoming: legal rules can be pervasive and worthwhile comparing without appearing at the pinnacle of the hierarchy of norms. To grasp what these rules might be, empirical research on the administrative state can be of assistance. The principal example of this form of interdisciplinary analysis is my discussion of organized interests: the government commissions, public-sector management committees, and self-regulatory powers that enable organized interests to influence the administrative process are generally ignored in conventional legal scholarship, but are recognized as central to national systems of interest representation in the political science literature. 
Empirical research can also bring to light important consequences of law which are difficult to discern from a purely legal analysis of the rules. For example, in discussing administrative accountability to elected officials, I dwell on the difference between presidential and parliamentary regimes. A strictly legal reading of the powers of prime ministers and presidents would probably not warrant my extensive treatment of the topic since, at first blush, their powers over the bureaucracy appear to be largely identical. However, political science research suggests that these legal powers, when exercised in the broader institutional context of presidential and parliamentary government, operate quite differently, with a significant impact on the nature of administrative decision making.

To be sure, there is an obvious objection to my four-part characterization of accountability networks: how can any one set of legal standards and procedures be identified with any one set of actors and accountability relations? Elected officials, organized interests, courts, and members of the public are simultaneously involved in almost every form of legal rule and procedure that governs the administrative process. Elected officials use their powers in response to demands from individual constituents and lobbying groups; the procedures that enable organized interests to shape administrative policymaking also benefit elected representatives and the general public; adjudication in the courts is triggered by persons and organizations adversely affected by bureaucratic decision making; and transparency empowers not only individual citizens but also reinforces judicial oversight and increases the influence of organized interests. But even though democratic politics are complex, in most cases it is possible to identify one set of actors, with their distinctive priorities and logics of action, that benefit from the rules of administrative law. The constitutional powers of elected officials are exercised primarily with a view to re-election; the procedures that call for public participation in regulatory policymaking are used most effectively by organized interests; the legal standards that historically have been developed by the courts reflect judicial notions of fair play and individual rights; and transparency guarantees and ombudsman procedures allow individual members of the public, who might otherwise be excluded from the administrative process, to put pressure on public officials. Another way of understanding the distinction between the four types of accountability is to view them from the perspective of the public administration: does a particular set of rules constrain decision making because bureaucrats fear the loss of their legal powers at the hands of elected officials, opposition from organized members of the regulatory community, 
reversal based on judicial standards of fair play, or public embarrassment through revelations in the press and the public statements of parliamentary ombudsmen? Each type of accountability rule disciplines the work of civil servants in distinct ways, precisely because each type empowers a different set of network actors in the administrative process.

Before we turn to the actual work of comparison, a caveat is in order. Although I argue that accountability networks are common to the administrative law of all liberal democracies, the analysis here is focused mostly on the United States and Western Europe. Limited geographical scope is, perhaps unfortunately, a reality for most comparative research given the linguistic and legal skills necessary to understand different legal systems. This is particularly acute in administrative law, which has historically been considered peripheral to the discipline and therefore has not generated a substantial secondary literature. In the conclusion, I further discuss the resulting difficulties posed for my comparative framework and suggest future lines of research to fill the inevitable gaps left by the analysis here.

\section{The Four Accountability Relationships of Public Administration}

Before exploring the accountability network, it is necessary to take a step back and focus briefly on the organization bound by the network-public administration. What are the essential attributes and characteristics of public administration and how does it differ from other types of public institutions and private organizations? The answer lies in the system of civil service employment that arose in the late nineteenth century and that is still at the core of public administration: the selection and promotion of public officials based on merit and insulated from political influence through tenured employment. ${ }^{35}$ The legal guarantees of civil service employment emerged to serve multiple ends: autocratic rulers seeking to consolidate their authority (Prussia), political elites adapting the instruments of government to the demands of industrialization and urbanization (Britain), and government reformers intent on shielding government from the instability and incompetence of appointments based on party patronage (United States and France). In Europe, Japan, and North America, civil service safeguards were

\footnotetext{
${ }^{35}$ On the history and development of the civil service in the United States, see SKOWRONEK, supra note 6. On the history of the civil service in Europe, see CIVIL SERVICE SySteMs IN WESTERN EUROPE (Hans A.G.M. Bekke \& Frits M. van der Meer eds., 2000); ZILLER, supra note 28.
} 
introduced over the course of the nineteenth century: beginning in the 1840s in France, 1870 in Britain, 1873 in Prussia, 1882 in Canada, 1887 in Japan, and 1883 in the United States.

Modern civil service laws are designed to render public employees independent of partisan politics and competent to perform the business of the nation. Some legal systems go so far as to constitutionalize this ambition, including the Italian Constitution (Article 97) and the German Grundgesetz (Article 33). The core features of civil service employment are: (1) life tenure absent grave misconduct; (2) merit-based recruitment; (3) promotion based on a mixture of seniority and merit (often accompanied by independent civil service commissions); (4) pay scales and benefits that are more standardized than in private enterprise; and (5) limitations on political campaigning, freedom of expression, and union activities, although these restrictions are far less common now than in the past.

One important difference in the organization of the civil service is the avenue through which public employees are recruited. Beginning with the École des Ponts et Chaussées, founded in 1747 to train civil engineers, France has developed a system of prestigious statesponsored schools, designed to educate the future elites of the civil service. The most famous of these is the highly selective École Nationale d'Administration, which funnels its graduates into the top echelons of the public administration based on a system that gives the highest-ranked graduates their first choice of sought-after positions in government ministries, public enterprises, and the highest administrative court, the Council of State. Other countries, by contrast, have relied on the existing system of higher education to supply the recruits for the upper ranks of the civil service: in Germany, the law faculties of the public university system followed by a traineeship in the courts, in Britain, Oxford, Cambridge, and, today, numerous other universities, and in the United States, the extensive network of public and private universities. Some countries, notably Italy and Argentina, have sought to copy the French model, by establishing their own state-sponsored civil service schools though success has been mixed due to a lack of support from those political actors that benefit from a patronage-driven model of recruitment. ${ }^{36}$

\footnotetext{
${ }^{36}$ See Lorenzo Saltari, Formazione e selezione dei dirigenti pubblici nell'ordinamento statale, negli ordinamenti regionali e negli altri stati, in LA DIRIGENZA DELLO STATO ED IL RUOLO DELLA SCUOLA SUPERIORE Di PUBBLICA AMMINISTRAZIONE 29 (Bernardo G. Mattarella ed., 2009), available at http://www.sspa.it.
} 
Notwithstanding the common impulse to develop a professionalized public administration, there remain significant differences in the degree to which recruitment is professional or political. At the top echelons of the bureaucracy, where political appointments enable democratically elected officials to give direction to the work of public administration, appointments by electoral winners are more extensive in the United States than in other countries. ${ }^{37}$ There are also significant differences at the lower levels of the bureaucracy, where political appointments operate less as an instrument of democracy and more as a resource to be used in the corrupt exchange relationships of patronage politics. Some countries appear to be particularly vulnerable to this form of party-based infiltration of public administration, notwithstanding a legal commitment to an independent, professionally competent civil service. Italy represents but one example of this phenomenon. There a number of mechanisms, related to Italy's multi-party system and the weak nature of party competition, have enabled political parties and party-affiliated trade unions to circumvent the civil service system and to distribute the spoils of the public administration largely among themselves. ${ }^{38}$

As many have observed, the past twenty years or so have witnessed a number of challenges worldwide to the traditional model of civil service employment. ${ }^{39}$ First and foremost is the wave of New Public Management reforms that hit most democracies the 1980s. Reformers in this vein have sought to render the public sector more efficient by making the terms of public sector employment-pay, benefits, and promotion-more flexible and by tying them more closely to performance indicators. Another strategy for improving efficiency has been to remove service-delivery functions from public administration and to contract them out to firms operating in the private sector. ${ }^{40}$ The magnitude of New Public Management reforms, however, varies dramatically among countries and tracks the extent to which the civil service model has historically permeated national bureaucracies: for instance, the contracting-out phenomenon is far less pervasive in Europe than in the United States, where even core state functions like

\footnotetext{
${ }^{37}$ See Richard Rose, Giving Direction to Government in Comparative Perspective, in THE EXECUTIVE BRANCH 72 (Joel D. Aberbach \& Mark A. Peterson eds., 2005); Barbara Nunberg, Ready for Europe: Public Administration Reform and European Union Accession in Central and Eastern Europe, World Bank Technical Paper No. 466, at 40 (2000).

${ }^{38}$ See Stefano Battini, Il Personale, in Il Sistema Amministrativo Italiano 279 (Luisa Torchia ed., 2009); Sabino Cassese, Hypotheses on the Italian Administrative System, 16 WeSt EuROPEAN POL. 325 (1993).

${ }^{39}$ See SUlEIMAN, supra note 18.

${ }^{40}$ See Jean-Bernard Auby, Contracting Out and 'Public Values,' in Comparative Administrative Law, supra note 2 , at 511 .
} 
running prisons and conducting military operations have been out-sourced to private contractors. ${ }^{41}$ A second challenge to the traditional model is the growing importance of party affiliation in obtaining top-ranking civil service positions in European parliamentary democracies. The number of political appointments, however, still lags far behind the United States and the nature of these appointments is different since they generally must be made from the ranks of the civil service, namely by selecting those who have both cultivated party ties and have made their career within the bureaucracy. In sum, the legal guarantees of meritocracy and tenured employment, along with the many variations that have been canvassed here, are still central to the notion of public administration across the globe.

\section{A. Administration and Elected Officials}

Max Weber famously depicted bureaucracy and the hierarchical, rule-bound nature of bureaucratic action — what he called legal-rational authority — as the hallmark of the modern state and the persistence of this model in comparative administrative law is a testament to the power of his theory. But Weber left unanswered a fundamental puzzle of bureaucratic authority: what would render the higher-level rules, at the source of bureaucratic action, themselves legitimate? Democracy was not part of his theory. In the hundred or so years since Weber wrote, however, competitive elections and representative governing bodies have become the norm and it has become commonplace to conceive of the rational authority exercised by bureaucracy as placed at the service of elected politicians. ${ }^{42}$ Thus today, accountability to elected officials constitutes one of the primary sources of administrative legitimacy and one of the principal constraints on administrative action. Indeed, in some accounts, elected officials represent not just one node of a complex accountability network, but rather the dominant node, responsible for designing the overall network and empowering or disenfranchising other network actors.

Bureaucracy, situated in this democratic context, has given rise to a number of common constitutional problems and doctrinal developments. One that should be mentioned here is the

\footnotetext{
${ }^{41}$ See Government By CONTRACT (Jody Freeman \& Martha Minow eds., 2009).

${ }^{42}$ In the legal literature, this has been called the "transmission-belt" theory of administration. See Richard B. Stewart, The Reformation of American Administrative Law, 88 HARV. L. REV. 1669 (1975). In the political science literature it is known as the "principal-agent" theory of administration. See McNollgast, The Political Origins of the Administrative Procedure Act, 15 J.L. ECON. \& ORG. 180 (1999); Kaare Strøm, Parliamentary Democracy and Delegation, in Delegation AND ACCOUnTABILITY IN PARliamentary DeMOcRACIES 55-106 (Kaare Strøm, Wolfgang Müller \& Torbjörn Bergman eds., 2003).
} 
concern that the prerogatives of the legislature, the branch of government generally considered to be the most directly connected to the democratic will, may be lost to the growing domain of public administration. The trend has been for government administration to amass substantial powers, in the face of both increasing scientific and social complexity and the internationalization of policymaking. Courts have sought to limit legislative delegations of policymaking power by developing doctrines that specify core areas of legislative action, which, as a matter of constitutional law, may not be ceded to public administration. For instance, in the United States, pursuant to the non-delegation doctrine, authorizing legislation must contain an "intelligible principle" capable of guiding bureaucrats, and in Germany, under Article 80 of the Basic Law, parliamentary laws must specify the "content, purpose, and scope" of the authority conferred. ${ }^{43}$ Most commentators have concluded that these constitutional principles have done little to stem the tide of executive dominance but they are nonetheless an important part of the doctrinal apparatus that has served to legitimate the administrative state.

Notwithstanding the widespread adoption of the common democratic institutions of universal suffrage, competitive elections, and representative government bodies, the design of democracy varies considerably from one country to the next. One of the major legal differences that separate political systems and that affect the relationship between elected officials and the bureaucracy is the distinction between parliamentary and presidential regimes. ${ }^{44}$ In parliamentary systems, the executive branch is dependent on the legislative branch: the governing cabinet is selected by the parliament and can survive only as long as it enjoys the confidence of the parliamentary majority. ${ }^{45}$ By contrast, in presidential systems, the executive branch is, in principle, independent of the legislature: the chief executive (the president) is selected by popular election, the terms of office of the executive and the legislature are fixed, the members of the government are chosen by the president, and the president exercises constitutionally independent lawmaking powers, the extent and scope of which, however, vary significantly among presidential regimes. In other words, in presidential systems, the electoral node of the accountability network is populated by two independent actors, whereas in parliamentary

\footnotetext{
43 See Peter L. Lindseth, The Paradox of Parliamentary Supremacy: Delegation, Democracy, and Dictatorship in Germany and France, 1920s-1950s, 113 YALE L.J. 1341 (2004).

${ }^{44}$ See Bruce Ackerman, The New Separation of Powers, 113 HARV. L. REV. 633 (2000).

45 Matthew Soberg Shugart \& John M. CAREY, PREsidents AND Assemblies: Constitutional Design AND ELECTORAL DYNAMICS 19 (1992).
} 
systems, it is composed of a single actor in the shape of a governing cabinet supported by parliament. While parliamentarism is the most common regime type worldwide, the United States, a number of Latin American countries, and other political systems are presidential regimes.

This democratic-design choice makes a difference for the law of public administration. In the constitutional law of parliamentary systems, the rise of the administrative state has created fewer problems because the bureaucracy can be depicted as part of a clear chain-of-command extending from the people to parliament to government to bureaucracy. At least as a matter of legal theory, the government's command powers over the bureaucracy are exclusive and public administration is legitimate because of its place in the chain-of-command. This understanding is expressed in theories of ministerial responsibility, which cast government ministers as a conduit between democratically elected parliaments and public administration: ministers are responsible for the actions taken by their ministries before parliament and have the power to direct and control the work of those under their command. ${ }^{46}$ By contrast, in the United States, both Congress and the President independently claim the power to direct public administration. The federal bureaucracy was famously denigrated as the "headless fourth branch" in the 1930s and the question of where administrative agencies fit in the Constitution's tripartite system of government persists today. ${ }^{47}$ Is public administration a tool of Congress or the President? And generally speaking, the answer is both.

In another contrast with American law, the parliamentarian understanding of bureaucracy as the tool of the executive, not the legislative branch, has given rise to varying degrees of constitutional resistance in Europe to the independent regulatory agencies that have been created over the past decades to supervise newly liberalized markets. ${ }^{48}$ These agencies are designed to be independent from the executive largely by limiting government control over the appointment and removal of top agency officials and by cutting off ministerial powers to review and revise the decisions made by agency officials. This was perceived as necessary to reassure investors and

\footnotetext{
${ }^{46}$ See ZILLER, supra note 28, at 115, 434.

${ }^{47}$ See, e.g., Peter L. Strauss, Overseer, or "The Decider"? The President in Administrative Law, 75 GEO. WASH. L. REV. 696 (2007); Keith E. Whittingon \& Daniel P. Carpenter, Executive Power in American Institutional Development, 1 PERSPECTIVES ON POLITICS 495 (2003).

${ }^{48}$ See Fabrizio Gilardi, Delegation in the Regulatory State: InDEPENDENT Regulatory Agencies in WESTERN EUROPE (2008).
} 
markets that public regulators would be impartial, in the context of newly liberalized markets in which some of the largest players were recently privatized state firms. Yet, because public administration belongs to the executive branch in constitutional theory, in Germany, relatively few independent agencies were created. Furthermore, in many countries (France, Germany, the United Kingdom), the powers of independent agencies were limited to prosecutorial and adjudicatory powers and did not include rulemaking powers, which were retained by government ministries. ${ }^{49}$ This stands in marked contrast with the United States, where administrative agencies independent of the President and entrusted with all three powers were among the first created during the Progressive Era and the New Deal. ${ }^{50}$ Although independent agencies were challenged at the time, the Supreme Court has consistently allowed them on condition that Congress does not directly decide on the appointment and removal of agency officials and that it does not assign core executive prerogatives such as the foreign affairs power to such agencies. ${ }^{51}$

The parliamentary versus presidential design choice affects not only the constitutional law of administration but also the politics of administrative action. The critical difference between the regime types for our present purpose is the possibility of divided government in presidential systems: because the legislature and the chief executive are selected independently, for fixed terms, the legislature and the executive branch can be led by different political parties. ${ }^{52}$ It is during periods of divided government that the electoral node of the accountability network in presidential systems operates most distinctively. Political scientists have observed two particularities of American administration which they ascribe to the competition between Congress and the President during periods of divided government: the simultaneous politicization and legalization of administrative action.

\footnotetext{
${ }^{49}$ See Jens-Peter Schneider, Regulation and Europeanisation as Key Patterns of Change in Administrative Law, in THE TRANSFORMATION OF ADMINISTRATIVE LAW IN EUROPE 309 (Matthias Ruffert ed., 2007); see generally Dominque Custos, Independent Administrative Authorities in France, in COMPARATIVE ADMINISTRATIVE LAW, supra note 2, at 277, 280; Daniel Halberstam, The Promise of Comparative Administrative Law, in COMPARATIVE ADMINISTRATIVE LAW, supra note 2, at 185, 195-99.

${ }^{50}$ See Humphrey's Executor v. United States, 295 U.S. 602 (1935).

${ }^{51}$ See Stephen G. BReYer ET AL., AdMINISTRATIVE LAW AND REGUlATORY POLICY 76-102 (6th ed. 2006).

${ }^{52}$ For this reason, many consider France's semi-presidential system to be closer to a classic parliamentary regime than to American presidentialism. If the party that controls the legislature is different from the one that wins the presidency, executive power rests largely with the prime minister, not the president. Only if the president and the parliament are of the same party, can the president exercise sweeping prerogatives over the government cabinet and the executive branch. In other words, the French constitution avoids divided government.
} 
In American presidentialism and European parliamentarism, the instruments of political control are broadly similar: the political appointment and removal of top officials, instructions contained in everything from formal laws to informal departmental circulars, and decisions on appropriations and program funding. ${ }^{53}$ However, in the American presidential system, these control tools are shared between the legislative and executive branches, with significant competition between the two branches in seeking to direct the bureaucracy during periods of divided government. In parliamentary systems, by contrast, the pivotal role of governing cabinets ensures that political control of administration is exercised primarily by the executive, with little competition from a legislature seeking to interject an alternative set of priorities.

A number of studies have demonstrated that as a result of the American system of divided control, even career bureaucrats are forced to engage in broad coalition-building among the multiple political forces that exercise influence through Congress and the President, to promote and defend their programs. ${ }^{54}$ Their work is permeated by politics. By contrast, in parliamentary systems, the role of politics is at one and the same time more direct and less omnipresent. Bureaucrats are not expected to promote their pet initiatives and defend existing programs against budget cuts. That is the domain of the government cabinet and ministerial offices that give them instructions and is the subject of negotiation and compromise among the elected politicians that constitute the government.

Somewhat counter intuitively, presidentialism has also been blamed for the greater legalization of the American administrative process. In the United States, statutes designed to save the environment, protect consumers, and accomplish a variety of other public aims are thought to be more detailed and to require more extensive administrative procedures than elsewhere. ${ }^{55}$ This regulatory style both denies bureaucrats flexibility and empowers lawyers and courts by making legal challenges easier to bring and by giving individuals the right to participate in the administrative process. According to public choice scholars, the difference can be explained by the competitive relationship between Congress and the President: detailed laws and elaborate procedures are designed to protect the political bargain struck in Congress once policy implementation is put in the hands of the bureaucracy and subject to the potentially very

\footnotetext{
${ }^{53}$ See Rose, supra note 37 , at 78-90.

${ }^{54}$ See Ackerman, supra note 44.

${ }^{55}$ See Robert A. KAGAN, AdVERSARIAL Legalism 3 (2001).
} 
different political agenda of the President. ${ }^{56}$ In a parliamentary system, this legalization strategy is neither possible nor attractive: not possible because any restrictions enacted by the legislature can be undone the moment that a new government is elected into office and not attractive because the efficiency costs of legalization far outweigh the possible benefits. ${ }^{57}$

\section{B. Administration and Organized Interests}

Social and economic actors like organized religions, employer and labor groups, environmental associations, large firms, and farmer organizations are centers of power and authority in their own right. They command extensive material and ideational resources and mobilize large numbers of citizens. Therefore, even though legal scholarship has been reluctant to admit it because of the traditional focus on expert administration, societal actors often combine with the bureaucracy to make public policy and constitute an essential node of administrative accountability networks. Administrative law shapes the socio-economic dimension of accountability networks in two, related ways: it creates opportunities for organized interests to participate in the decision-making of public administration and it allows social and economic actors to self-regulate, thus limiting state intervention and encouraging private governance in various policy areas.

Interest organizations participate in public life by advising on government policymaking and engaging in self-regulation in most administrative law systems. Take the law of land-use planning and environmental permitting. In countries as diverse as Britain, Brazil, Mexico, Canada, France, Italy, Japan, and the United States, public administration is required, by law, to give notice of any planned decision to the local community, to receive written comments, and to hold a public hearing. ${ }^{58}$ This enables residents, business interests, and environmental groups to mobilize for and against administrative decisions at the local level. Lawyers are a good example of the self-regulation strand of group participation. In the United States, Europe, and elsewhere,

\footnotetext{
${ }^{56}$ See David Epstein \& Sharyn O’Halloran, Delegating Powers (1999).

${ }^{57}$ See Terry Moe \& Michael Caldwell, The Institutional Foundations of Democratic Government, 150 JouRnAL OF INSTITUTIONAL AND THEORETICAL ECONOMICS 171 (1994).

58 See Michel Prieur, Droit De L'ENVIRONNMEnt (5th ed. 2004) (France); Lei 9.985/2000 (Brazil); CAROL HARLOW \& RICHARD RAWLINGS, LAW AND ADMINISTRATION 573-74, 582-88 (3d ed. 2009) (England); Gabriella Pavon \& Jose Juan Gonzalez, Land Use Planning in Mexico, in LAND Use LaW FOR SuSTAINABLE DeVElopMENT 484-502 (Nathalie J. Chalifour et al. eds., 2007); Canadian Environmental Protection Act §§ 73,74; Aldo Sandulli, Il Procedimento, in TratTato Di DiRITTO AMministrativo 1035-1342 (Sabino Cassese et al. eds., 2d ed. 2003) (Italy); Ho Chin SiOng, AN InTRODUCTION TO JAPANESE City PLANNING 65 (2003).
} 
the right to practice law is regulated almost entirely by the profession, with very little supervision by the state. ${ }^{59}$ The officially recognized bar association sets the terms of entry into the profession, determines the rules that govern professional practice, and administers the disciplinary proceedings designed to punish lawyers who transgress the rules. The disciplinary decisions of lawyer associations are generally subject to judicial review by the courts and their proposed standards and rules must often be approved by government ministries or supreme courts before they can take effect, but on the whole public oversight is minimal. Associations of accountants, engineers, and architects are other common examples of organized interests that are empowered by administrative law to self-regulate and, therefore, to occupy policy spaces largely free from the intervention of bureaucracy.

Notwithstanding these commonalties, a number of broad-brush differences can be observed between - as they are called in the political science literature - the American pluralist and European neo-corporatist systems of interest representation. ${ }^{60}$ Although for many observers neo-corporatism connotes the grand, tri-partite European wage agreements that were entered into by governments, labor, and industry in the 1970s and early 1980s, this form of interest representation, as well as the pluralist alternative, reaches all the way down into the lower strata of administrative policymaking and program implementation. There are two important differences that separate pluralism from neo-corporatism and that shape this facet of administrative accountability networks. The first turns on the organizational capacity of intermediate associations while the second goes to the extent to which the state and civil society are intermingled and private groups are given public powers. In many (neo-corporatist) European legal systems, producer groups such as workers and employers are organized into a few, allencompassing and broadly representative labor unions and employer associations. These organizations are given privileged access to the process of making and implementing public policy and are conferred significant self-regulatory powers. The latter powers, even though they are of the self-regulatory variety, are constrained by government supervision and the duty to

\footnotetext{
${ }^{59}$ See, e.g., Deborah L Rhode \& David Luban, Legal Ethics 113-29 (5th ed. 2009) (United States); JoËL Moret-BAILly, Les DÉONTOlogies 102-10 (2001) (France); Maria da Gloria Bonelli, Lawyers' Associations and the Brazilian State, 1843-1997, 28 LAW \& SOC. INQUIRY 1045 (2003).

${ }^{60}$ Philippe C. Schmitter, Still the Century of Corporatism?, in TRENDS TOWARD CORPORATIST INTERMEDIATION 13, 15, 27-28 (Philippe C. Schmitter \& Gerhard Lehmbruch eds., 1979); Gerhard Lehmbruch, Introduction, in PATTERNS OF CORPORATIST POLICY-MAKING 1,16-23 (Gerhard Lehmbruch \& Philippe C. Schmitter eds., 1982); Wolfgang Streeck, The Study of Organized Interests, in THE DIVERSITY OF DEMOCRACY 3, 17-18, 29-30 (Colin Crouch \& Wolfgang Streeck eds., 2006).
} 
consult outside interests. As politics have changed and non-material interests have become more prominent, the neo-corporatist accountability model has been extended to environmental and consumer protection groups, human rights organizations, and other types of associations.

By contrast, in the (pluralist) American legal system, industry associations and trade unions can rarely claim to represent all firms or workers operating in a particular industry and, as a result, it is highly unusual to give a particular association or set of associations an official role in the policymaking process. Rather, administrative policymaking is left wide open to influence from multiple, competing interest groups, often seeking to speak for the very same constituents, and the implementation of government policies rarely depends upon official collaboration with specific interest organizations. Moreover, compared with Europe, private associations exercise self-regulatory powers less frequently. Indeed, in American administrative law, the agents of self-regulation are generally individual firms, not industry associations, and therefore, in contrast to Europe, the type of authority wielded does not occupy an intermediate space between state and market: firms are prompted to self-regulate either by the incentives of the market, for instance a better brand name, or by the threat of state action, for instance a possible enforcement action, but not by virtue of institutionalized pressure from other firms or countervailing labor groups. Furthermore, in the pluralist accountability model, even when private associations do selfregulate, it is less common for them to obtain a legal monopoly on their activities or to be subject to state-imposed requirements. In other words, the American legal system is hostile towards the mixing of private and public powers that is characteristic of organizational life in Europe.

The corporatist-pluralist difference has both long-standing and more recent causes. The pre-modern guild system was, for obvious reasons, stronger in European countries than in the United States and has survived the vicissitudes of democratization better than in the United States. In the twentieth century, the European labor movement was considerably more successful than its American counterpart in organizing workers, influencing politics, and obtaining institutional representation. ${ }^{61}$ These successes not only led to counter-mobilization by industry and the formation of powerful business associations but also to the extension of the mixed public-private model to other civil society actors such as environmental and human rights

${ }^{61}$ See Graham K. Wilson, Why Is There No Corporatism in the United States? in PATTERNS OF CORPORATIST POLICY-MAKING 219, 232 (Gerhard Lehhbruch \& Philippe C. Schmitter eds., 1982). 
groups. It should be noted that, over the past two decades, neo-corporatist governance arrangements have been scaled back. As everywhere else, trade union membership in European countries has declined and the power of industry associations over their member firms, especially the giants of the global marketplace, has diminished. Moreover, in an effort to remove institutional obstacles to their privatization and liberalization agendas, a number of European governments have reduced the official role for intermediate associations in policymaking. Nonetheless, compared to the United States, the organizational capacity of labor and industry remains extraordinary and their role in the policymaking process, together with that of a newer generation of advocacy groups, still stands out when contrasted with the public-private divide in American administrative law.

The different legal practices are also linked to different political theories of the state and society. In Europe, the idea of the state placed at the service of society has long been popular. This intellectual current is well represented by the French theory of public services explored earlier: the purpose of public administration was to support and bind together the various social and economic groups that constituted the complex social whole. These ideas were developed in the law by thinkers such as Laski in England, von Gierke in Germany, Duguit and Hauriou in France, and Santi Romano in Italy but were notably absent from the debates of the American legal realists. ${ }^{62}$ By contrast, the United States is the land of James Madison, Arthur Bentley, and David Truman. ${ }^{63}$ In their pluralist theories of interest group politics, theories which Richard Stewart astutely observed over thirty years ago have directly shaped American administrative law, society was cast as a never-ending array of self-serving interests constantly in competition with one another. ${ }^{64}$ The role of government was fairly passive: a set of neutral rules that would impartially arbitrate among the different demands put forward by competing interests and thereby enable state officials to forge policies in the public interest. One way of summarizing these American and European differences is with the contrasting metaphors of interconnected solidarities and vigorous competition. While limitations on private access to public policymaking, the conferral of public powers upon private organizations, and public regulation

\footnotetext{
${ }^{62}$ This literature is far too vast to canvass here. For an excellent introduction to this strand of French intellectual history, see J.E.S. Hayward, Solidarist Syndicalism, 8 SocIOLOGICAL REVIEW 17 (1960).

${ }^{63}$ See Daniel J. Tichenor \& Richard A. Harris, The Development of Interest Group Politics in America, 8 ANNU. REV. POL. SCI. 251, 251-52 (2005).

${ }^{64}$ Stewart, supra note 42 , at 1712.
} 
of private ordering have traditionally been viewed with suspicion in American legal circles as unfairly meddling with the competitive process necessary to achieve public well-being, they are accepted tools of social integration and the public interest in European law.

There are numerous examples of the difference between neo-corporatist and pluralist accountability networks. An emblematic feature of the pluralist American system of interest representation is notice-and-comment rulemaking. ${ }^{65}$ In this procedure, the public has a right to receive advance notice of all rules promulgated by the bureaucracy, give their views on such rules, and receive a detailed response to their objections from the administration. ${ }^{66}$ With noticeand-comment rulemaking, all competing interests with the necessary resources have access to the policymaking process. Contrast this with the favorite method of obtaining outside input on regulatory initiatives in France, Italy, and many other European systems: policy-specific advisory committees created by law, selected by the government, and composed of representatives of the major interest group organizations active in the policy area. ${ }^{67}$ In national systems, as well as the European Union, there are hundreds of these committees in areas as diverse as welfare and industrial policy, consumer affairs, environmental policy, and equal protection. It is certainly true that, today, European regulators also stage broad-based consultations, using the possibilities afforded by the internet to make their policy proposals widely known and to solicit the reactions of all those organizations that care to comment so that the privileged access of the past has been attenuated somewhat through the use of new technologies. ${ }^{68}$ However, in contrast with American notice-and-comment rulemaking, these consultations are permeated by administrative discretion, both in the decision to call them in the first place and subsequently, in the decision on what kind of response, if any, to give to public

\footnotetext{
${ }^{65}$ Id. at $1775-77$.

${ }^{66}$ There have been attempts to devise alternatives to notice-and-comment rulemaking, which has been criticized as conflictual and time-consuming, but they have had only limited success. See,.e.g., Philip J. Harter, Collaboration, J. DiSP. RESOL. 411, 440-41 (2009).

${ }^{67}$ See, e.g., JeAn CAlais-Auloy \& FRAnK Steinmetz, Droit DE LA CONSOMMATION 26-27 (5th ed. 2000); Sabino Cassese, Amministrazione pubblica e interessi in Italia, DIRITTO E SOCIETÀ 223 (1992); SUSAN ROSE-ACKERMAN,

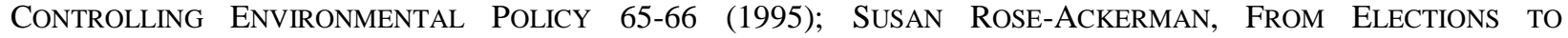
DeMocracy: Building ACCOUnTABle Government In Hungary AND POLAND 131, 185, 203 (2005). Perhaps the paradigmatic example of neo-corporatist interest representation is the institution of the Social and Economic Council. This institution exists in Italy, France, the Netherlands, and the European Union, and is tasked with advising the government and parliament on legislative initiatives. See J.E.S. HAYWARD, PRIVATE INTERESTS AND PUBliC POLICY (1966). Today, however, most agree that their influence over lawmaking is minimal, whereas the policy-specific committees discussed in the text continue to serve an important fact-finding and advisory function.

${ }^{68}$ See, e.g., Dorit Rubinstein Reiss, Participation in Governance from a Comparative Perspective, J. DISP. RESOL. 381 (2009).
} 
opposition; as a result, regulators are still in a strong position to control access to the policymaking process.

Moving from policymaking to policy implementation, in much of continental Europe, labor, employer and professional groups are entrusted by law with the day-to-day administration of the welfare state, something that in the United States is left either to the bureaucracy or, increasingly, to the market. For instance, in France, members of the management boards of public entities responsible for various forms of social assistance are selected by the major labor unions and employer organizations. ${ }^{69}$ In Germany, tri-partite governing boards composed of employer, labor, and state representatives manage the social security agencies responsible for health insurance, pensions, and unemployment insurance. ${ }^{70}$ Historically, tri-partite management boards and consultative committees were particularly omnipresent in Sweden and the Netherlands, although it is true that since the 1990 s, they have been scaled back. ${ }^{71}$ Looking beyond social assistance programs to the implementation of other types of government policy, intermediate associations are given an official role there too. In Sweden, Denmark, and the Netherlands, appeals from all types of administrative decisions have traditionally been through a system of specialized government boards, many of which have interest group representation. In Denmark, for instance, the denial of an environmental permit is subject to appeal to a government board consisting of a member of the judiciary, representatives of industry, and environmental advocates appointed by the Environmental Protection Agency. ${ }^{72}$

Let us, finally, consider the corporatist-pluralist difference with regard to the question of self-regulation by network actors. In France, dozens of professional associations, ranging from doctors, to veterinarians, to ski instructors, produce codes of conduct (codes de déontologie), subject to varying degrees of state supervision, and then are charged with enforcing these codes through a system of layman justice that is subject to review by the highest courts. ${ }^{73}$ The same

\footnotetext{
${ }^{69}$ See JEAN-JACQUES DUPEYROUX, DroIT DE LA SÉCURITÉ SOCIALE (14th ed. 2001).

70 See MANFRED Weiss \& MARLENE SCHMIDT, LABOUR LAW AND INDUSTRIAL RELATIONS IN GERMANY (4th ed. 2008).

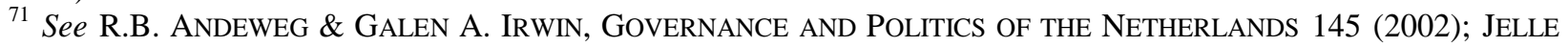
ViSSER \& ANTON HEMERIJCK, A DUTCH MIRACLE 169, 172 (1997).

72 Danish Environmental Protection Act, Chapter 12.

${ }^{73}$ See MORET-BAILLY, supra note 59. In the political science literature, many do not consider France to be a neocorporatist system because labor and employer groups are poorly organized and because of the hostility of republican theory to particularistic interests. However, the mixing of public and private powers that is characteristic of neo-corporatism is present in the French case too. See John T. S. Keeler, Corporatism and Official Union
} 
phenomenon can be observed in Germany, Italy, and many other countries. Likewise, local chambers of commerce exercise significant, state-sanctioned power over their members. In Germany, for instance, local businesses and tradesmen are required by law to join their local chambers of commerce. These chambers represent their members before the government, run vocational training programs and apprenticeships, and, in the case of the tradesmen chambers, devise quality-related regulations which, if breached, can result in the loss of the right to exercise the trade. ${ }^{74}$ The pervasiveness of self-regulation in Europe stands in contrast with the United States, where comparatively few professions are granted licensing privileges and local chambers of commerce are purely voluntary organizations, with mostly social and representational functions, not regulatory ones. ${ }^{75}$

Another difference in the self-regulatory space carved out by administrative law lies in the degree of state supervision of private associations - higher in neo-corporatist accountability networks, lower in pluralist accountability networks. Industry-sponsored standard-setting is a good example of the contrast. In the United States, there are hundreds of industry organizations which operate unregulated by government and which commonly produce competing standards from which manufacturers can choose. ${ }^{76}$ By contrast, in Germany, there is one peak industry association, the Deutsches Institut für Normung (DIN), composed of many different sections, each devoted to a particular economic sector and technology. ${ }^{77}$ DIN's powers stem from an industry-government agreement, under which DIN was given a legal monopoly over standardsetting. In return, it was required to establish a five-member Consumer Council and was directed to take into consideration public interest goals. This tightly woven fabric of private powers and public control is characteristic of industry standard-setting throughout Europe.

Hegemony, in ORganizIng InTERESTS IN WESTERN EuROPE 185 (Suzanne Berger ed., 1981). Moreover, as Pierre Rosanvallon has pointed out, the institutional practice of French democracy creates significant space for organized interests and therefore the standard republican image of French politics is highly misleading. The law and practice of French administrative governance is a good illustration of the mismatch between what Rosanvallon calls "the representation and the reality." PIERRE Rosanvallon, The DeMANDS OF LiBERTY 3 (Arthur Goldhammer trans., 2007).

${ }^{74}$ See JIM SWEENEY, EMPLOYER AND EMPLOYEE CHAMBERS IN GERMAN SPEAKING COUNTRIES (1996).

75 See, e.g., Jörg Finsinger, Doctors, in REGULATION OF PROFESSIONS 377, 389, 391, 392 (Michael Faure et al. eds., 1993) (demonstrating that in the United States the medical profession enjoys fewer self-regulatory powers than in Germany, Belgium, the Netherlands, and the United Kingdom).

${ }^{76}$ See Walter Mattli \&Tim Buthe, Setting International Standards, 56 WorLd Politics 1, 23-25 (2003).

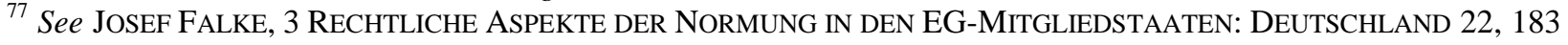
(2000); HARM SCHEPEL \& JOSEF FALKE, 1 LEGAL ASPECTS OF STANDARDisATION IN THE MEMBER STATES OF THE EC AND EFTA: COMPARATIVE REPORT 76 (2000). 


\section{Administration and the Courts}

\section{Systems of Judicial Review}

The emergence of bureaucratic power in the late-nineteenth and early-twentieth centuries was closely tied to the question of justice. What was to be the relationship between the old mode of exercising public authority, through trials and courts, and this new form of state power, designed to expeditiously raise taxes, undertake public works, protect public health, and more? The right to contest administrative decisions in a trial before a state official removed from the original determination emerged as a key element of bureaucratic authority in both civil law and common law systems. It was thought to be critical to the fairness and legitimacy of public administration. At the same time, there also emerged what has conventionally been portrayed as the major dividing line separating national legal systems and their organization of the judicial component of administrative accountability networks: judicial review powers vested in the ordinary courts of law in England versus litigation before a specialized body connected to the executive branch in France. In other words, the difference between the English common law and French administrative law (droit administratif) was born.

The origins of this institutional divide are extremely complex and have been the object of numerous distinguished historical studies. ${ }^{78}$ For our purposes, it is enough to recall the very different political circumstances surrounding the rise of bureaucracy and administrative law in France and England. In France, the consolidation of state power in the seventeenth and eighteenth centuries was marked by intense conflicts between the royal officers charged with administering the provinces (intendants) and powerful regional courts (Parlements) that were composed of local elites and that exercised a variety of what, today, would be called judicial, legislative, and executive functions. Insulating intendants from interference by local Parlements through the creation of a separate system of administrative justice controlled by the king was critical to the centralization of state power and the establishment of absolute monarchy. This impulse in favor of a specialized review body was carried into the French Revolution, albeit

\footnotetext{
78 See, e.g., J.W.F. Allison, A Continental Distinction In The Common LaW (2003); Sabino Cassese, La costruzione del diritto amministrativo, in TRATTATO DI DIRITTO AMMINISTRATIVO 1-93 (Sabino Cassese, ed., 2d ed. 2003); MARCo D’Alberti, DiritTo AMMINISTRATIVO COMPARATO (1992); MANNORI \& SORDI, supra note 7, at 8586; J.D.B. Mitchell, The Causes and Effects of the Absence of a System of Public Law in England, PUBLIC LAW 95, 96-101 (1965).
} 
motivated by a different set of rationales. In the republican theory of the Revolution, the general will had to be protected from the special privileges and particularistic interests of the Ancien Régime. The courts, which were associated with the old elites, were denied any power over administration and instead a special body, believed to be more sympathetic to the demands of the nation and the people, was established to oversee government administration. Although the powers of the Council of State, as this review body was known, were initially quite meek, by 1872 it had acquired the power to decide individual disputes on its own authority, without having to obtain government approval as had been the case previously.

England, by contrast, did not experience the same conflicts between local elites and central monarchy. William the Conqueror inherited what was, for the epoque, a remarkably cohesive system of self-governing local entities (shires, hundreds, and boroughs) united under a single ruler and overseen by officers loyal to the king. ${ }^{79}$ When the old Anglo-Saxon and Norman institutions fell into decline and eventually disappeared, they were replaced not by officers of the Crown but by various local bodies, most notably Justices of the Peace. ${ }^{80}$ These were members of the landed gentry who served as unpaid agents of the Crown and were responsible for everything from policing, to hearing low-level criminal and civil cases, to administering the poor tax, to licensing public establishments, to maintaining roads and bridges. Justices of the Peace remained the lynchpin of local administration for centuries. Only in the 1800s, when it became clear that lay administration was incapable of handling the complex demands of urbanization and industrialization, were they gradually replaced by a more professionalized and centralized administration. Throughout this time, appeals against the decisions of Justices of the Peace, other local government bodies, and crown officers rested with courts of general jurisdiction, through the same system of common law writs devised for private disputes. The possibility of a separate system of administrative justice did arise in the early 1600s, with the creation of royal prerogative courts that quickly came to rival the older common law courts for jurisdiction over disputes of various kinds. The Star Chamber, in particular, heard complaints against the decisions of Justices of the Peace and other local officials. This embryonic system, however, came to an end with the victory of Parliament and the common law bar over the monarchy in the revolutionary settlement of 1688; the hated prerogative courts were abolished and the

\footnotetext{
${ }^{79}$ See Thomas ERTMAN, BIRTH OF THE LEVIATHAN 158-66 (1997).

${ }^{80} \mathrm{See}$ COLIN RHYS LOVELl, ENGLISH CONSTITUTIONAL AND LEGAL HiSTORY 207-452 (1962).
} 
independence of common law judges was formally established by act of Parliament. It was at this time that the system of dual control of administration, which still is highly influential in English administrative law thinking, was put into place: on the on hand, parliamentary oversight of political issues decided by government officers and, on the other hand, common-law judicial review of administrative decisions for legality.

What then is the common law-droit administratif divide? How do different systems organize the judicial node of their administrative accountability networks? Even though much has changed since 1885, when the English legal scholar Albert Venn Dicey famously proclaimed that England had no such thing as a special branch of law called "administrative law," two important differences between the English and the French model remain. ${ }^{81}$ The first is institutional. In England and other common law countries, generalist judges retain the power to hear challenges to the acts and decisions of government administration. By contrast, in France, the body authorized to hear challenges - the Council of State-is considered part of the executive branch. ${ }^{82}$ The Council of State's system of recruitment, promotion, and management of personnel is entirely different from that of the judicial branch and gives rise to pronounced cultural and sociological affinities between public administration and the Council of State. Members are selected from graduates of the École Nationale d'Administration, the elite, staterun school designed to train the uppermost echelons of the civil service, and from the ranks of experienced individuals already serving in the administration, either in the lower administrative courts or in the upper ranks of the civil service. Moreover, at any given point in time, about onethird of the members of the Council of State serve elsewhere in public administration, in ministerial cabinets, public enterprises, and other government offices. The last distinguishing feature of the Council of State as compared to the judicial branch is that it has the dual function of regulating and adjudicating: it is composed of five administrative sections, responsible for giving technical advice on legislation and regulation, and one adjudicatory section, which hears administrative law cases. It is extremely common for Council members to be assigned simultaneously to both an administrative section and the adjudicatory section. Especially for outside observers, it bears mentioning that notwithstanding the overlap between the dispute-

\footnotetext{
${ }^{81}$ INTRODUCTION TO THE STUDY OF THE LAW OF THE CONSTITUTION (1885).

${ }^{82}$ This discussion of the Council of State is drawn largely from FROMONT, supra note 29.
} 
resolution and advisory functions of the Council of State, adjudication in the Council of State is fiercely independent, as much so as in the ordinary courts. ${ }^{83}$

The second major common law-droit administratif difference is doctrinal. Although common law jurisdictions operate with legal principles that are informed by the special circumstances of public administration, there is no clearly articulated conceptual divide separating public law from private law. By contrast, administrative law in France has evolved as a theoretically free-standing area of legal doctrine defined by a number of core principles that set it sharply apart from private law. In classic French theory, the state is granted extraordinary powers (the prerogatives of the puissance publique) at the same as it is subject to extensive duties designed to safeguard the public liberties of French citizens. ${ }^{84}$ One clear illustration of this reciprocal relationship is the important notion of public service: once a government activity is classified as a "public service," the state is empowered to take whatever measures are necessary to ensure the continuity of that service and adaptation to changing circumstances, but it is also under a duty to treat the users of the public service equally and neutrally. The state may unilaterally modify contracts to guarantee continuity and adaptability but it is also required to compensate fully the provider for any loss suffered as a consequence. This theoretical apparatus of powers and duties extends to all areas of administrative activity, as the contracts example illustrates, and thus, in French law, government liability and public contracts are treated as integral to the field of administrative law, unlike common law systems where they are considered closer to the private law of contract and torts.

The French divide between public law and private law is also apparent in the system of administrative litigation. Litigation against public administration is conceived in markedly different terms from private law litigation: it is designed primarily to ensure the (objective) legality of government action in a republican system faithful to the rule of law, not to vindicate (subjective) individual rights. ${ }^{85}$ This understanding of administrative law litigation has had

\footnotetext{
${ }^{83}$ Unlike members of the judiciary, members of the Council of State do not enjoy a formal guarantee of permanence in office (inamovibilité), meaning that, in theory, they can be transferred from one post to another for any reason, not only in the case of disciplinary sanctions. In practice, however, the government never uses these powers and it would be unthinkable for it to do so. There are also various other legal guarantees that ensure independence. See Jean Massot, The Powers and Duties of the French Administrative Judge, in COMPARATIVE AdMINISTRATIVE LAW, supra note 2 , at 415, 416-17.

${ }^{84}$ See generally ElIZABETH ZOLLER, INTRODUCTION TO PUBLIC LAW: A COMPARATIVE STUDY 250-60 (2008).

${ }^{85}$ See Fromont, supra note 29, at 164.
} 
numerous consequences. In contrast with the English common law, individuals are easily afforded standing to challenge generally applicable rules because even though they cannot claim the violation of a particularized right, they are thought to have an interest in the objective correctness of the rule. Another particularity was, until recently, an undeveloped system of judicial remedies that failed to protect fully individual rights: before 1980, the Council of State could annul offending administrative acts but it did not have the injunctive powers necessary to force the administration to comply with its judgments. ${ }^{86}$

In many ways, the self-contained doctrinal apparatus of droit administratif is coming apart: less of what public administration does is afforded the special treatment of "public services, ${ }^{, 87}$ the rules on public contracts and government liability are borrowing more and more from private law, ${ }^{88}$ and the subjective rights dimension of administrative law litigation has assumed enormous importance. ${ }^{89}$ Nevertheless, it is impossible to understand the legal constructs of French scholars and the reasoning deployed by French courts without some appreciation of the doctrinal uniqueness of administrative law.

An alternative to the English and French models of judicial review has emerged in the form of a specialized branch of the judiciary dedicated to hearing administrative law cases. The first example is generally taken to be Germany under the Basic Law of $1949 .{ }^{90}$ In the 1800 s, as in many other continental jurisdictions, scholars were divided over whether judicial control should be allocated to ordinary courts, the institutional solution believed to be most faithful to the new liberal values of the age, or to special administrative courts, perceived as a more pragmatic and feasible alternative that would reconcile executive prerogatives with rule-of-law ideals. $^{91}$ The latter model prevailed and, by 1900, administrative courts had been established

\footnotetext{
${ }^{86}$ Since the 1980s, however, the Council of State has gradually acquired better remedial powers, first with the power to fine non-compliant administration (astreinte), then with the power to issue injunctions (injonction), and finally with the power to grant temporary injunctions (référé). See id. at 168.

${ }^{87}$ See Etienne Picard, The Public-Private Divide in French Law Through the History and Destiny of French Administrative Law, in THE PUblic-Private LAW DividE: Potential FOR TRANSFORMATIOn?, supra note 2, at 17, 79.

${ }^{88}$ See Jacques Petit, A Reappraisal of the Distinction Between Administrative Contracts and Private Legal Contracts in French Law, in THE PUBLIC-PRIVATE LAW Divide: Potential FOR TRANSFORMATION?, supra note 2, at 283.

${ }^{89}$ See Fromont, supra note 29, at 18.

${ }^{90}$ See id. at 128.

${ }^{91}$ See STOLLEIS, supra note 7, at 216-90; Kenneth F. Ledford, Formalizing the Rule of Law in Prussia, 37 CENTRAL EUROPEAN HISTORY 203 (2004).
} 
virtually everywhere, including the powerful Supreme Administrative Law Court of Prussia. After World War II, as with most institutions of the German state, the system of administrative justice was entirely reworked. Today the judicial branch is composed of the Federal Constitutional Court and five discrete judicial hierarchies, one for civil and criminal law, one for labor disputes, one for tax disputes, one for social security disputes, and one for administrative law disputes. The latter three all handle variants of what would be called administrative law cases in other countries. The judges that serve on the tax, social security, and administrative law courts are recruited based on the same system of university study, exams, and traineeships as their counterparts on other courts and share the same guarantee of independence. The only difference is the degree of specialization and familiarity that the members of these three branches acquire with administrative law disputes. This form of judicial review operates closer to the common law model than the French one. In Germany, public contracts and government liability cases are heard by the civil courts, not administrative courts, and the legal doctrine tracks the private law of contract and tort. Moreover, administrative litigation is designed mainly to protect subjective rights and therefore individual standing is more limited than in France while, at the same time, the remedial powers of courts are broader.

Most legal systems have adopted one of these three institutional models. Histories of colonial rule can go some way in explaining the patterns we see today. The systems that were part of the British Empire and that adopted the common law have entrusted generalist courts with hearing disputes between individuals and the public administration. These include Australia, New Zealand, India, Ireland, and the United States. With the influence of American law after World War II, a number of other countries have also adopted the generalist court model, including Japan and South Korea. Countries that came under the French sphere of influence in the 1800s and the first half of the 1900s, today have Councils of State that operate separate from the ordinary judiciary. These include Belgium, the Netherlands, Luxembourg, Italy, Greece, Turkey, Lebanon, Egypt, Colombia, Morocco, Algeria, and Senegal. ${ }^{92}$ The label, however, can be deceptive, since some of these Councils of State only have policymaking powers (e.g., Luxembourg) and some only have powers of adjudication and are housed within the generalist court of last resort for civil and penal disputes (e.g., Morocco, Algeria, and Senegal). Moreover,

${ }^{92}$ Yves Gaudemet, L'exportation du droit administratif français, in MÉLANGES PHILIPPE ARDANT 431, 438 (1999). 
unlike the French model, jurisdiction over government liability cases in Belgium, Italy, and the Netherlands is vested in the ordinary courts, not the Council of State, on the liberal theory that ordinary courts are best placed to protect individual rights against harmful state action. It appears that the third form of judicial review, conducted by a specialized branch of the judiciary, is even more widespread that the other two models: it has been adopted in Austria, Portugal, Luxembourg, Sweden, Finland, the Czech Republic, Poland, Spain, Switzerland, Hungary, Slovenia, Romania, Estonia, Lithuania, and most of Latin America.

\section{Principles of Administrative Action}

\section{a. Procedural Principles}

One of the important features that traditionally distinguished judicial actors in the common law tradition from those in continental systems was their reliance on procedural principles of fair play in judging the correctness of administrative determinations. ${ }^{93}$ Common law courts tended to equate broad categories of administrative action with adjudication by courts and to require analogous procedural safeguards. ${ }^{94}$ By contrast, courts in continental Europe were more focused on the substantive correctness of administrative determinations in deciding whether or not to let them stand. In other words, in the common law tradition, the judicial accountability relationship was concerned primarily with procedure rather than substance while the reverse was true in continental systems. Doctrinally, the English insistence on administrative procedure was expressed by the principle of natural justice, which included the right to be heard and the rule against bias. The French equivalent, known as rights of the defense (droits de la défense), included fewer rights to an oral hearing and the disclosure of documents, and applied only to those administrative determinations that were considered sanctions.

Since the 1970s, however, this common law-continental law difference has faded. A number of national laws guarantee individuals, in the context of individualized administrative determinations, the right to receive notice of the proposed decision, to respond in writing, and to receive a statement of reasons with the final decision. These include the French laws of July 11,

\footnotetext{
93 This discussion only covers the procedural principles governing individualized administrative determinations, since they originated historically with courts and the standards of fair administrative action imposed by courts. For a discussion of the comparative procedure of administrative rulemaking, where the initiative has rested largely with lawmakers, see the discussion in Part IV.B of this Article.

${ }^{94}$ See Mitchell, supra note 78, at 106-09.
} 
1979 and April 12, 2000, the Italian law of August 7, 1990, the Swedish Administrative Procedure Act of 1986, and the Danish Public Administration Act of 1985. The German case is somewhat exceptional in that the proceduralization of individual decision making began immediately in the post-World War II period under the heavy influence of constitutional law and was eventually codified with the Federal Administrative Procedure Act of 1976. Spain is another interesting case: early on, notice and hearing procedures for licensing, procurement, and other types of decisions were set down in the Administrative Procedure Act of 1889. Many Latin American countries have adopted administrative procedure laws: Peru in 1972, Argentina in 1973, Costa Rica in 1978, and Columbia in $1984 .{ }^{95}$ The trend toward the proceduralization of individualized administrative determinations can also be observed in East Asia: Japan adopted an Administrative Procedure Act in 1993 and South Korea in $1995 .^{96}$

Notwithstanding this common procedural trajectory, there continue to be differences of which one in particular bears mentioning. Common law countries have institutionalized the judicial model within the bureaucracy to a greater extent than other legal systems. In Britain and Australia this takes the shape of administrative tribunals, while in the United States, it comes under the heading of formal adjudication, governed by the Administrative Procedure Act of 1946 and handled by administrative law judges. ${ }^{97}$ Administrative tribunals and administrative law judges are responsible for hearing appeals from social security determinations, immigration decisions, and other high-volume regulatory areas. They enjoy significant statutory guarantees of independence and their decision-making procedure is modeled after the courtroom, albeit with less formality. Individuals can appeal their determinations before the courts, but such challenges are brought infrequently and are limited to points of law. By contrast, even though individuals in continental systems are entitled to appeal administrative determinations up the bureaucratic chain-of-command, their only opportunity for an independent hearing is in judicial review before a full-fledged court.

\section{b. Substantive Principles}

In reviewing the substance of an administrative decision to ban a product on safety grounds, turn down a building permit for a supermarket, deny reimbursement for medical services, or

\footnotetext{
95 See Alan R. BREWER-CARIAS, ETUdES DE DROIT PUBLIC COMPARÉ (2001).

${ }^{96}$ See Tom Ginsburg, Dismantling the "Developmental State," 48 AM. J. COMP. L. 585 (2001).

${ }^{97}$ See Peter Cane, Judicial Review in the Age of Tribunals, 2009 PUBLIC LAW 479.
} 
accomplish one of the thousands of other purposes of the bureaucracy, what criteria do courts employ $?^{98}$ A multitude of doctrinal labels are used by courts to examine the work of bureaucrats and hold them accountable. Nevertheless, the substantive role of courts in administrative accountability networks can be seen to fall under three distinct headings: the rule of law, individual rights, and policy rationality. In the section below, I explore the local expressions of these judicial review practices and discuss the important variations in how, and the extent to which, these powers are exercised.

Influenced by the first-generation scholarship discussed earlier, much of judicial review is geared towards preserving the rule of law, understood as the principle of a government of laws and not of men. ${ }^{99}$ The activity of public administration must respect the purposes and limits set down in laws - generally passed by parliaments, but also in some places executive decrees — or turn into the arbitrary action of despots. The task of courts is to enforce those limits. To appreciate the pervasiveness of this understanding of the relationship between courts and bureaucracy, it suffices to peruse the main types of challenges contemplated in the administrative law of France, the United States, and England: administrative determinations can be overturned in France in the case of a "violation of the law," "in excess of statutory jurisdiction, authority, or limitations, or short of statutory right,"101 and in England in the event of "illegality," traditionally understood as part of "ultra vires" review. 102

A second type of substantive review of administrative action is the protection of basic liberties against government action. This was true even in the absence of written constitutions enforceable by the courts, given the importance of liberal property rights in both the common law writ system and continental civil codes. However, with the spread of written constitutions

\footnotetext{
${ }^{98}$ Due to space constraints, the principles of government torts and public contracts are omitted from this discussion.

${ }^{99}$ I take this as the minimalist, lowest-common-denominator definition of rule of law. However, it is also important to note that the definition of rule of law varies considerably from one legal system to the next. Among the most comprehensive conceptions is probably the one developed in Germany after World War II, which includes fundamental rights, social justice, and the separation of powers as part of the definition of "law" and which requires that all administrative action be authorized by parliamentary law, with very little role for inherent executive powers as in the French and the English systems. See Bell, supra note 27, at 1272.

${ }^{100}$ FROMONT, supra note 29, at 167. This is one of four grounds of review under the general action for "excess of power" (excès de pouvoir).

${ }^{101}$ Administrative Procedure Act $\S 706(2)(C)$. In practice, however, most litigation alleging that government administration exceeded its statutory powers is brought under the provision permitting challenges to be brought against administrative decisions that are "arbitrary, capricious, an abuse of discretion or otherwise not in accordance with law." Administrative Procedure Act § 706(2)(A).

${ }^{102}$ Paul Craig, Administrative LaW 5-18, 531-49 (6th ed. 2008).
} 
and constitutional courts in the twentieth century, as well as international human rights instruments, in particular the European Convention of Human Rights, the scrutiny applied by courts has become far more rigorous and the rights protected in the face of administrative action have expanded tremendously — freedom of expression and association, the right to privacy and human dignity, personal liberty, the right to exercise various forms of economic activity, and more.

The role of courts in safeguarding fundamental rights in the administrative process is most spectacular in Germany. ${ }^{103}$ There administrative law has been thoroughly constitutionalized, more so than elsewhere in Europe and the United States. As the President of the Federal Administrative Court declared in 1959, administrative law is "concretised constitutional law" (konkretisiertes Verfassungsrecht). ${ }^{104}$ The result has been extensive judicial review of administrative action in the name of rights. A number of German doctrines have since gone on to influence the rest of Europe through the European Court of Justice, the European Court of Human Rights, and the intense transnational networks that exist among European legal elites. ${ }^{105}$ Three in particular bear mentioning: proportionality, equality, and legitimate expectations.

Under German law, any measure that interferes with a right must survive a proportionality inquiry, meaning that the public administration must satisfy a sequential inquiry: (1) the measure is capable of achieving the declared public ends; (2) the measure is necessary for achieving those ends and no other, equally effective and less rights-restrictive measures are available to accomplish the same ends; and (3) the public purpose of the measure outweighs the burden to the individual right. To illustrate: In 1958, the Constitutional Court declared an administrative restriction on the number of pharmacies in operation to be a disproportionate interference with the right to freely choose one's profession. The German courts engage in a similar inquiry when administrative programs are challenged due to alleged discrimination based on economic or other characteristics: under the equality principle "[d]ifferences must be of such

\footnotetext{
103 For this discussion of constitutional principles in German administrative law, see George Nolte, General Principles of German and European Administrative Law, 57 THE MODERN LAW REVIEW 191 (1994).

${ }^{104} I d$. at 201.

${ }^{105}$ FrOMONT, supra note 29, at 255, 256, 262.
} 
a kind and weight so as to justify a differentiation." 106 And the principle of legitimate expectations, the rough equivalent of the duty of non-retroactivity in the United States, significantly limits the ability of public administration to reverse benefit-conferring determinations. As a result of this doctrine, recipients of agricultural subsidies, housing benefits, and other forms of government largess have a right to compensation or considerable notice (generally one year) if the government decides to reduce the amount of the benefit or to withdraw a benefit improperly granted. ${ }^{107}$ The rights dimension of German administrative governance stands in marked contrast with the United States, where the Supreme Court has long given up on reviewing government action that burdens economic rights. ${ }^{108}$ Rational-basis review, under the Fourteenth Amendment of the Constitution, is the standard that applies, and it is well known to be an extremely lenient test which rarely stands in the way of legislative or administrative action.

The last form of judicial accountability relationship is review for policy rationality. Doctrinally, rationality review picks up where rule-of-law review leaves off: even though legislation might not contain standards to guide administrative action and therefore effectively leaves decision-making to the discretion of bureaucrats, the courts nonetheless can evaluate administrative action based on criteria related to sound policymaking. Doctrinal expressions of this form of review give the impression that only acts of confirmed insanity will be struck down by the courts: review for "arbitrary and capricious" decision-making in the United States under the Administrative Procedure $\mathrm{Act}^{109}$ and review for "manifest error of assessment" (erreur manifeste d'appréciation) in France. ${ }^{110}$ Even more impressive is the articulation of the principle in English law:

By "irrationality" I mean what can now be succinctly referred to as "Wednesbury unreasonableness"... . It applies to a decision which is so outrageous in its defiance of logic or accepted moral standards that no sensible person who had applied his mind to the question to be decided could have arrived at it ... ${ }^{111}$

\footnotetext{
10685 BVerfGE 191, 210 (1992).

${ }^{107}$ See Edward J. Eberle, The West German Administrative Procedure Act, 3 DiCKINSON J. INT'L L. 67 (1984).

${ }^{108}$ See Bruce ACKerman, We the PeOPle: Transformations (1998).

${ }^{109}$ Administrative Procedure Act $\$ 706(2)(\mathrm{A})$.

${ }^{110}$ See FromONT, supra note 29, at 238.

${ }^{111}$ Council of Civil Service Unions v. Minister for the Civil Service [1985] AC 374, Lord Diplock.
} 
In the United States, however, rationality review, which doctrinally speaking falls under the heading of "arbitrary and capricious" and not under the weaker form of constitutional rationalbasis review, has become an extremely demanding test, and has come to represent a distinctive feature of the American administrative law system. ${ }^{112}$ It became common judicial practice in the late 1960s and the 1970s — when it became known as "hard look review"-and was associated with the fall of the post-war consensus on economic growth, growing distrust in government, new social movements, and the spread of public-interest lawyering. As the Supreme Court said in State Farm:

[T] he agency must examine the relevant data and articulate a satisfactory explanation for its action including a "rational connection between the facts found and the choice made." ... Normally, an agency rule would be arbitrary and capricious if the agency has relied on factors which Congress has not intended it to consider, entirely failed to consider an important aspect of the problem, offered an explanation for its decision that runs counter to the evidence before the agency or is so implausible that it could not be ascribed to a difference in view or the product of agency expertise .... ${ }^{113}$

Although European rights-based proportionality review and American rationality review overlap in some respects, their essence is fundamentally different. In the former, the focus is on the individual right and the decision to reverse an administrative act turns on an assessment of the importance of the right as compared to the public purpose as well as the ability of the administration to articulate a close connection between the government measure and the public purpose. In the latter, the focus is on the quality of the science and policy assessments behind the administrative decision, with a considerable burden placed on the government to refute the alternative scientific evidence and policy options put forward by opponents of the decision.

\section{Administration and the Public}

Over the past forty years or so, administrative accountability networks have expanded considerably. Individuals acting directly, without having to go to the ballot box, engage in socioeconomic mobilization, or persuade the courts to take their case, have become important players in accountability networks. This informal, broad-ranging public oversight has become critical to the legitimacy of bureaucracy. Although diffuse public accountability is achieved by virtue of a

\footnotetext{
${ }^{112}$ See KAGAN, supra note 55; $c f$. RoSE-ACKERMAN, supra note 67, at 87-93.

${ }^{113}$ Motor Vehicle Manufacturers Ass'n v. State Farm, 463 U.S. 29, 43 (1983).
} 
wide array of legal tools and institutional arrangements, two are particularly prominent: ombudsmen appointed by parliaments with oversight and complaint-resolution functions and laws guaranteeing all citizens a right of access to government documents. Sweden is generally believed to be the first Western legal system to have established an ombudsman and freedom of information. There, the early expansion of parliamentary power at the expense of the king led to a right of access to government documents (Law on Liberty of the Press, enacted in 1766 and reenacted in 1809) and the establishment of a parliamentary ombudsman (1809). ${ }^{114}$ For a long time, Sweden stood out as an anomaly, but beginning in the 1970s, momentum gathered in a number of countries for broader public accountability in government administration and today a vast array of legal systems have freedom-of-information laws and ombudsmen. ${ }^{115}$

Ombudsmen share a number of characteristics. ${ }^{116}$ They are institutionally linked to parliaments, not the executive branch, by virtue of the fact that they are appointed by parliament, generally for a fixed term, and are legally obligated to report periodically on their activities. The principal function of ombudsmen is to settle complaints filed by members of the public against the bureaucracy. The process is informal: a simple letter or online complaint form is sufficient to trigger an investigation; the grounds for complaining are extraordinarily broad and do not need to be styled as one of the grounds for obtaining legal redress in the courts. "The officer was extremely rude" or "I never received an answer to the query that I filed with the tax office" is enough to warrant a response from the ombudsman. ${ }^{117}$ The ombudsman system, therefore, offers the promise of redress to individuals without the resources to go to court and in circumstances that fail to meet the often stringent legal criteria that have been developed by courts to make a successful claim against the administration.

Once the ombudsman comes to a decision on a complaint, the powers of his or her office are limited compared to courts. The ombudsman cannot order the administration or civil servant to comply with his or her views but rather must rely on other network actors and the threat of bad

\footnotetext{
${ }^{114}$ See Bengt Wieslander, The PARliamentary OMbUdSMAN IN SWEDEN 11-16 (1994) (ombudsman); Donald C. Rowat, Rapport General, in LE SECRET ADMINISTRATIF DANS LES PAYS DÉVELOPPÉS 21, 27-29 ( 1977) (access to documents).

115 See Rowat, supra note 114, at 21-25.

116 Early accounts include WALTER GELLHORN, OMBUDSMEN AND OTHERS (1966) and DONALD ROWAT, THE OMBUDSMAN (1968). A good example of the more recent literature is KATYA HEEDE, EUROPEAN OMBUDSMAN (2000). For an overview of a number of similar government bodies, see John M. Ackerman, Understanding Independent Accountability Agencies, in COMPARATIVE ADMINISTRATIVE LAW, supra note 2, at 265.

${ }^{117}$ See, e.g., The European Ombudsman, The European Code of Good Administrative Behavior, art. 12.
} 
press, public embarrassment, and parliamentary pressure to induce compliance. ${ }^{118}$ This triangular relationship between ombudsman, press, and parliament is critical to the effectiveness of the institution. ${ }^{119}$ The threat of public censure and hostile parliamentary questions is the main tool in the ombudsman's arsenal and underscores the diffuse public accountability inherent in this area of administrative law. Ombudsmen in Sweden, France, Demark and many other countries are also involved in policymaking and regularly recommend changes to administrative law and practice to bring the administration into line with rule-of-law ideals and fundamental-rights guarantees.

Laws on the right of access to public documents also broaden public oversight of administration and enable individuals to play an important role in accountability networks. ${ }^{120}$ The right to view government documents can be understood as expanding public scrutiny by giving individuals an opportunity to examine the decisions of government even absent a claim of having been wronged or of having a particular interest in the matter. Simply by virtue of being a citizen, individuals are assumed to have a stake in the correct workings of their public administration and, therefore, to have a right to access to government documents. Freedom-ofinformation laws, however, also restrict the types of documents that are accessible. For instance, industry documents that contain commercial secrets and documents related to national security are either excluded or subject to extensive redaction before they may be released to the public. Preliminary drafts, notes, and memoranda are entirely exempted from disclosure in Sweden and Denmark if they are never circulated outside the responsible government agency and are exempted until the relevant government decision becomes final in Finland and the United States. Laws also differ in how they organize access to documents: in Sweden, Finland, and the European Union, there are official registers of government documents that are open to the public and that assist the public with formulating their access requests, while in Denmark, the Netherlands, and the United States, no such registers exist and individuals proceed by specifying the issue of interest and leaving it entirely to public administration to locate the relevant documents.

\footnotetext{
118 On the enforcement dimension, the powers of the Swedish ombudsman are exceptional because it can initiate disciplinary proceedings and bring criminal prosecutions against individual civil servants and therefore it is more powerful than most of its peers.

${ }_{119}$ See Rowat, supra note 114, at 34-39.

${ }^{120}$ See John M. Ackerman \& Irma E. Sandoval-Ballesteros, The Global Explosion of Freedom of Information Laws, 58 ADMINISTRATIVE LAW REVIEW 85 (2006).
} 
Both ombudsmen and freedom-of-information laws have been popular over the past decades. In Europe, Finland (1919), Denmark (1954), Britain (1967), France (1973), Spain (1981), the Netherlands (1984), Ireland (1984), Portugal (1991), and Romania (1991) have established ombudsmen at the national level, and other countries, like Germany and Italy, have created them on a regional basis. ${ }^{121}$ New Zealand (1962), Hong Kong (1989), and Korea (1994) are examples of other countries with parliamentary ombudsmen. As for freedom of information, according to one study, almost seventy countries throughout the world have adopted the necessary legislation. $^{122}$

This country overview gives an idea not only of the extent of diffuse public accountability as a feature of administrative law, but also of the differences that remain among legal systems and their accountability networks. The degree to which individuals seek formal recognition of their grievances through the courts or rely mostly on informal avenues of redress through ombudsmen is still a source of comparative variation. In some countries, parliamentary ombudsmen are absent, as in the United States and Germany (at the federal level), and in other countries, parliamentary ombudsmen have a reputation for being ineffective. By contrast, in systems like Sweden and Denmark, the informal dispute settlement and accountability offered by ombudsmen is immensely popular and tends to function as a substitute for courts. Freedom-ofinformation laws also have not taken root everywhere. Just in Europe, Italy and Greece are notable exceptions to the trend. Viewed positively, this might be a collective choice in favor of representative democracy over direct democracy or a vote of confidence in a expert bureaucracy, but less charitably, the absence of a right of access is an indicator of a powerful bureaucracy resistant to change and outside scrutiny.

\section{CONCLUSION}

The ambition of this Article has been to develop a conceptual framework for comparative administrative law that is attuned to the realities of administrative governance in liberal democracies today. Administrative law can no longer be understood as simply a set of rules that

\footnotetext{
121 For a complete list of European ombudsmen, see The European Network of Ombudsmen, http: //www.ombudsman.europa.eu/atyourservice/nationalombudsmen.faces.

${ }^{122}$ PRIVACY INTERNATIONAL (DAVID BANISAR), FREEDOM OF INFORMATION AROUND THE WORLD 2006: A GLOBAL SURVEY OF ACCESS TO GOVERNMENT INFORMATION LAWS (2006).
} 
enable effective public administration and that afford individuals judicial redress should the boundaries of authorizing legislation be overstepped by government bureaucrats. Today, most observers recognize that civil servants are embedded in a dense accountability network of public and private actors and that administrative outcomes are driven by the complex set of legal relations that constitute the network. This novelty is part representation and part reality: the delegitimization of bureaucracy has brought to light rules, procedures and actors that have always existed but were previously obscured by the dominant paradigm of expert administration, while, simultaneously, the loss of confidence in public administration has given rise to legal innovations that have expanded the accountability network and have empowered a variety of public and private actors. This is the changed administrative landscape that my comparative framework seeks to capture and that serves to structure my comparison of European legal systems and the United States.

With this new paradigm in hand, comparative law is better equipped to speak to contemporary debates on administrative governance. In the literature on administrative reform, the tendency is to stereotype what came before: administration was hierarchical and technocratic, closed to outside scrutiny, and reliant on command-and-control techniques. The way forward, the reformers argue, is to bring in public transparency, political accountability, and administrative collaboration with private industry and other stakeholders. Yet, as the comparative analysis demonstrates, once we go beyond the old intellectual paradigm of administrative organization and judicial review, not all government administration fits the stereotype-not even in the early days of administrative law and certainly not today. An appreciation of this great diversity and wealth of legal possibilities can assist in devising reform, as well as in understanding the consequences of reform across different administrative law settings.

What are some of these possibilities and consequences? The European technique of managed self-regulation may be appropriate for concentrated market sectors in the United States, in which competition between industry actors, not to mention their self-regulating industry associations, is de facto absent so that one cannot rely on pluralist rivalry between overlapping interest groups to produce public-regarding outcomes. Vice versa, pluralist notice-and-comment rulemaking could be adopted by European systems in areas such as anti-discrimination law in which the policy question - minority rights - appears to call for a variety of perspectives that are 
not easily represented by a few, all-encompassing interest organizations. More searching constitutional scrutiny of administrative decision-making could be considered by American courts, while at the same time, rigorous rationality review may be warranted in European tribunals. The United States should give more thought to establishing independent watchdogs akin to parliamentary ombudsmen, especially now that digital technologies have made it so easy for individual citizens to voice their grievances to these trusted intermediaries. All these possibilities apply not only to domestic administrative law, but also extend to international and transnational systems of administrative governance. How should political accountability, interest group representation, judicial review, and diffuse accountability be organized in the European Union, the World Trade Organization, transnational networks of banking regulators, and other sites of global governance? The natural first place to look is to domestic systems of administrative law, with their numerous legal variations, long histories, and rich experience.

By the same token, an appreciation of legal differences suggests the limits of universal reform ambitions in their national settings and fosters a better understanding of the legal and institutional constraints that shape the path of administrative governance. As I indicated earlier, it appears that New Public Management reforms have been less extensive in Europe compared to the United States because of the greater importance of the civil service tradition in European legal systems. In Europe, independent regulatory agencies have proliferated over the past twenty years, but their powers and numbers still lag behind those of their American cousins at least in part because of the different constitutional constraints of parliamentary government. It seems that the empowerment of the private sector through collaborative governance and self-regulation can be expected to operate quite differently in neo-corporatist and pluralist regimes: while European systems have highly organized labor and employer groups and a tradition of public management of private governance, in the United States, trade unions and industry associations are weak and legal barriers insulate private ordering from public interference.

There is another area of inquiry suggested by my comparative framework: Do concepts and comparisons that are largely based on European legal systems and the United States travel to liberal democracies elsewhere in the world? To take but one example: do the comparative observations on the differences between presidential and parliamentary regimes, drawn mostly from the contrast between the United States and Britain, hold for other systems? In Latin 
America, Russia, and other presidential systems, the executive decree powers of the directly elected president are stronger than the powers of the American president. ${ }^{123}$ Therefore, in contrast with the United States, presidents in Latin American and Russia might very well dominate public administration, without much competition from the legislative branch; as a result, these systems might resemble more closely parliamentary systems than the U.S. presidential model because of the extent to which political control of the bureaucracy is concentrated in the executive. ${ }^{124}$

It is, however, not only the geographic coverage of the suggested framework that deserves to be expanded, but also its legal and empirical content. Relations between courts and public administration are the most developed part of my analysis. This is a reflection of the concerns that have traditionally dominated comparative administrative law and at the same time demonstrates the importance of more primary research on the dimensions of administrative governance designed to foster electoral oversight, diffuse accountability, and the participation of social and economic groups. In short, a comparative framework that focuses not on the expert administration of legislative directives but on a complex accountability network of public and private actors generates a host of new research opportunities and dramatically expands the potential insights of comparative administrative law.

\footnotetext{
${ }^{123}$ See EXECUTIVE DeCREe Authority (John M. Carey \& Matthew Soberg Shugart eds., 1998).

${ }^{124}$ Cf. Mariana Mota Prado, Presidential Dominance from a Comparative Perspective, in COMPARATIVE ADMINISTRATIVE LAW, supra note 2, at 225.
} 